\author{
В.П. Варакута, О.О. Кумпан, Т.В. Хліманцов, В.О. Іванов, Г.В. Заверуха \\ Військовий інститут танкових військ Національного технічного університету \\ “Харківський політехнічний інститут”, Харків
}

\title{
ВИЗНАЧЕННЯ КРИТЕРІЇВ I ПОКАЗНИКІВ ЕФЕКТИВНОСТІ ОБОРОННОЇ СИСТЕМИ ТА РОЗРОБЛЕННЯ МОДЕЛІ СИЛ І ЗАСОБІВ ОПЕРАТИВНО-ТАКТИЧНОГО УГРУПУВАННЯ ДЛЯ ОБҐРУНТУВАННЯ ПРОПОЗИЦІЙ ЩОДО ПРИЙНЯТТЯ РІШЕННЯ НА ОБОРОНУ
}

У статті на понятійному рівні розглянута сутність $i$ зміст понять “критерій” $i$ “показник” та їх значення під час оцінки ефективності оборонної системи військового угрупування. Запропоновані математичні моделі та розроблена методика визначення пріоритетних критеріїв і показників ефективності оборонної системи та надані обгрунтовані пропозиції щзодо шляхів створення ефективної оборонної системи оперативно-тактичного угрупування.

Ключові слова: критерії, показники, математичні моделі, ефективність, оперативно-тактичне угрупування, прийняття рішень, раціональне рішення, елементи оборонної системи, сили $і$ засоби, система управління.

\section{Вступ}

Постановка проблеми. Суверенітет держави Україна забезпечується через створення та подальший ефективний розвиток відповідних інститутів влади, із яких однією 3 найважливіших є система забезпечення воєнної безпеки. Проведений аналіз [1-2] говорить про те, що, на жаль, ефективність функціонування деяких інститутів влади завдяки політично-економічним зовнішнім і внутрішнім важелям впливу залишається низькою. Це також стосується військової складової: управлінської діяльності командування операціями об'єднаних сил (OOC) та оперативно-тактичних угрупувань військ (ОТУ), які на смугах зіткнення стримують незаконні збройні формування (НЗФ) та російськосепаратистські військові формування від просування у глибину території країни [3].

Невиправдані втрати серед особового складу (бої під Іловайськом, в Дебальцевому та під Волновахою) говорять про те, що мають місце непродумані деякими командирами й начальниками рішення на оборонні дії. Прийняття рішення на бойові дії це складний творчий процес, де залучено багато військових фахівців. Наприклад, рішення, що приймає командир оперативно-тактичного угрупування (ОТУ) на оборону, складається з пропозицій посадових осіб за окремими напрямками бойового застосування родів військ, спеціальних військ та за видами забезпечення. Ці пропозиції за відповідними показниками повинні задовольняти вимогам обраних критеріїв. Сукупність цих пропозицій-альтернатив складає множину варіантів рішень. Кожний 3 них визначається експертним методом [4], що оцінює результат, отриманий шляхом моделювання, після чого цим варіантам рішень надається своє значення пріоритету. Визначені множини пропозицій-альтернатив ще називають пріоритетними множинами [5]. Під пріоритетними множинами розуміються множини пропозицій-альтернатив за складовими рішень на якісь дії (у даному випадку на оборону), що задовольняють визначеним показникам i відібрані з врахуванням базового набору звісних критеріїв, за якими оцінюються окремі складові або рішення в цілому. У відповідності з [5] визначена низка пріоритетних завдань системи забезпечення воєнної безпеки та запропоновано методику визначення пріоритетних завдань системи забезпечення загальної воєнної безпеки на основі знаходження домінуючих завдань. Проте не конкретизовані, а під час не визначені критерії та показники, що характеризують тактико-оперативні властивості оборонної системи (ОС) на конкретному оперативно-тактичному напрямку проти конкретного противника за наявністю конкретного угрупування військ в обороні.

Тому, доцільно дослідити й визначити критерії й показники ефективності ОС, розглянути математичні моделі динаміки оборонних дій сил і засобів та об'єктів оборони (Сi3 та Ооб) ОС. Адже вони сприяють в надаванні командиру ОТУ більш обгрунтованих пропозицій та створюють умови більш якісного прийняття ним управлінського рішення на оборону для побудови більш ефективної ОС.

Аналіз останніх досліджень і публікацій. Більшість наукових досліджень зосереджено на вивченні окремих аспектів визначення й обгрунтування критеріїв, показників і оцінки результатів заходів щодо безпеки або оборонних дій сил і засобів (Сi3) OC, таких як опорних пунктів взводів і рот або ра- 
йонів оборони батальйонів. У той же час розгляд критеріїв та показників ефективності Сi3 ОС у цілісному вигляді, що складається із системи вогню сухопутних бригад, артилерії, ракетних і зенітноракетних військ та авіації та ін., в масштабах, наприклад, ОС ОТУ здійснюється вкрай рідко. Як наслідок, до сих пір відсутні теоретичні основи цієї проблеми. Хоча питання, що стосуються загальних критеріїв і показників та пріоритетів 3 множини елементів (варіантів рішень) щодо безпеки й оборони, достатньо детально розглянуті в роботах [4-5]. Теоретичне обгрунтування вищезгаданих критеріїв знайшло своє відображення в роботах [6-7]. Проте до теперішнього часу продовжується пошук більш точних та конкретних визначень критеріїв та показників ефективності різних видів військової діяльності, у тому числі оборони.

Метою статті $є$ визначення критеріїв і показників ефективності ОС ОТУ для обгрунтування пропозицій для прийняття рішення на оборону та дослідження математичної моделі динаміки оборонних дій Сi3 та Ооб як інструменту роботи командира й офіцерів штабу ОТУ під час процесу розроблення рішення на оборону.

\section{Виклад основного матеріалу}

В сучасній довідниковій літературі поняття “критерій” визначається як “ознака", на основі якої здійснюється оцінка, визначення, класифікація будьчого. Критерій розглядається як еталон, на основі якого здійснюється оцінка та порівняння результатів і виступає як основна ознака, за якою одне рішення вибирається із множини можливих. Так, в роботі [8] підкреслюється, що критерій - це мірило, ознака для оцінки, класифікації, судження, тобто ознака, що дозволяє із багатьох можливих рішень вибрати одне. В роботі [9] поняття “критерій” характеризується як засіб, за допомогою якого вимірюється рівень, ступінь прояву того або іншого явища й трактується як мірило оцінки суджень. За допомогою критерію виділяється перевага якого-небудь вибору у порівнянні $з$ тими, що залишилися та перевіряється відповідність результату меті, що поставлена або надається оцінка ступеню iї реалізації. 3 практичної точки зору критерії як визначені норми та правіла, дозволяють вирішити правильний наступний крок або ні, тобто раціональність якоїсь дії у цілому або іiі нераціональність. Критерій не фіксує найбільш перспективні й продуктивні принципи та способи дій, а тільки виражає об'єктивні закони й логіку розвитку явища (дії) [7].

В практиці досліджень розглядаються декілька підходів до визначення критеріїв та показників. Зокрема, критерій може бути інтерпретований як показник, на основі якого можна зробити висновок щодо ефективності, наприклад, ОС. За таким підхо- дом критерій є сукупністю основних показників, що розкривають визначений рівень ефективності ОС. Даний підхід характеризується тим, що ступінь сформованості критерію визначається шляхом фіксації його показників на різних рівнях ефективності. Тому, при обгрунтуванні критеріїв і показників, необхідних для комплексної оцінки ефективності ОС ОТУ та вироблення на його основі раціонального рішення на оборону, автори виходили із розглянутих методологічних положень в трактовці поняття “критерій” і “показник” в енциклопедичній та спеціальній літературі.

Отже, у загальному розумінні шуканий алгоритм розроблення пропозицій для вибору раціонального рішення на оборону передбачає:

на I етапі - формування множини пропозиційальтернатив для їх класифікації методом паретооптимізації, що дозволить відсікати у ході аналізу непридатні варіанти пропозицій до рішення;

на II етапі - формування пріоритетної множини пропозицій-альтернатив, які за визначеними показниками відповідають вимогам обраного критерію (критеріям);

на III етапі - формування необхідних обставин для вибору одного раціонального варіанту рішення 3 пріоритетної множини пропозицій-альтернатив.

У роботі Т.Л. Сааті [7] визначений непрямий метод рахування так званої функції приналежності для одного експерта. Використовуючи досвід офіцерів штабу ОТУ, метод дозволяє, залежно від поставленого бойового завдання, визначити експертним методом пріоритетну оцінку кожного критерію (варіанту дій) ефективності ОС. Далі на їх основі здійснюється вибір одного рішення на оборону як раціонального, який можливо здійснити за одним визначеним, наприклад, критерієм оцінки, або за допомогою математичних моделей складних систем, вирішити багатокритеріальну оцінку варіантів 3 пріоритетної множини обраних наборів критеріїв [5]. В набір раціональних варіантів рішень (пріоритетної множини) за обмежений час прийняття рішення може увійти до декількох варіантів, 3 яких треба вибрати, знов ж таки, одне.

Інформаційно-розрахункове забезпечення процесу прийняття рішення на оборону передбачає не тільки надання потрібної офіцерам штабу інформації, але й реалізацію розрахунків для обгрунтування пропозицій за варіантами рішення. При цьому бажано мати автоматизовану (комп'ютерну) систему оцінки пропозицій (АСОП), яка дозволяє оперативно швидко урахувати їх вплив на ефективність ОС у разі реалізації рішення із декількох варіантів. АСОП до варіантів рішення на оборону, як сукупність експертів, об'єктів, методик та методів оцінки, повинна підготувати відповідь на питання - яка буде ефективність та задовольняє вона чи ні вимогам команду- 
вання? При цьому потрібна відповідь на організаційні питання прийняття рішення на оборону: які відповідальні посадові особи та за якими напрямками призначаються, за якими чинниками, параметрами, показниками та критеріями оцінюються варіанти та окремі складові рішення.

Головну роль в системі оцінки рішень (СОР), що приймаються, безумовно, грає особисто командир ОТУ. Під час затвердження пропозицій він розраховує на те, що вони обгрунтовані й підтверджуються результатами моделювання, у ході якого посадові особи Центру оперативного управління (ЦОУ) за визначеними критеріями обрали кращі варіанти. Для цього доцільно використовувати структуру моделі, за допомогою якої буде здійснюватися реалізація АСОП до варіанту рішення, що приймається (рис. 1).

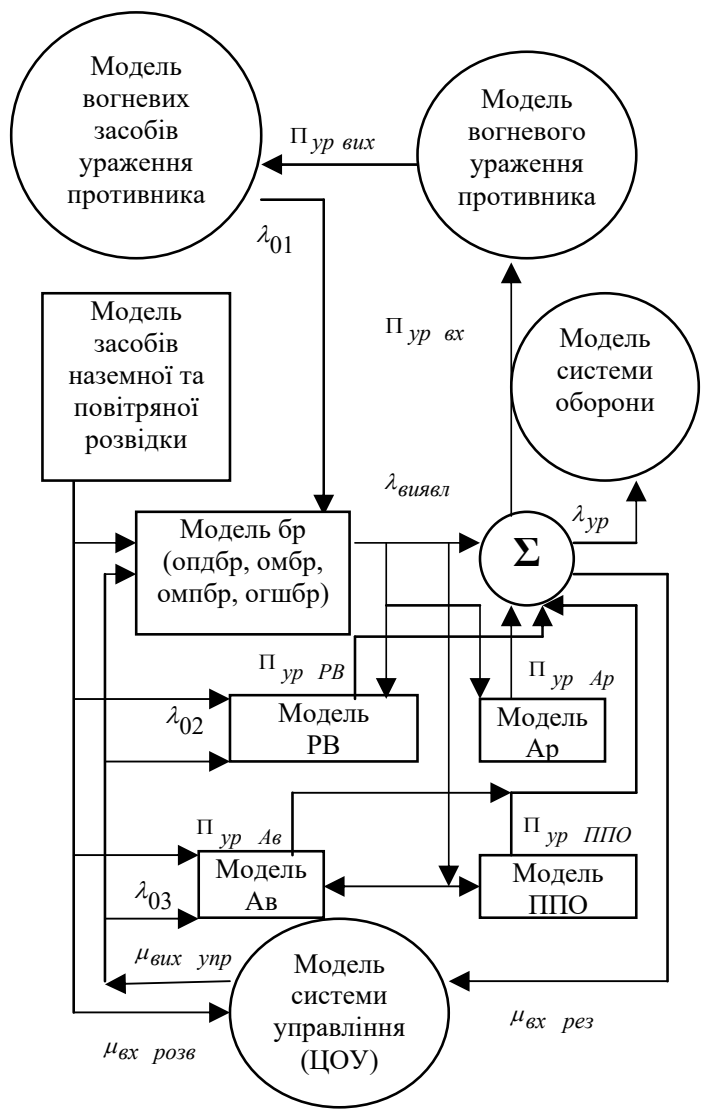

Рис. 1. Схема (варіант) моделювання інтенсивності оборонних дій Сі3 та Ооб ОС ОТУ, в якій здійснюється АСОП щодо варіантів рішення на оборону

На рис. 1 наведені окремі моделі Сі3 ОС ОТУ та їх взаємозв'язок через їх вхідні та вихідні інтенсивності:

$\lambda_{01}$ - інтенсивність входу вогневих засобів ураження (ВЗУ) противника в зону ураження опдбр, омбр, омпбр та огшбр;

$\lambda_{02}$ - інтенсивність входу ВЗУ противника в зону ураження ракетних військ і артилерії (Рв і Ар); $\lambda_{03}$ - інтенсивність входу ВЗУ противника в зону ураження авіації та засобів ППО (Ав і ППО);

$\lambda_{\text {виявл }}-$ інтенсивність видачі інформації про ВЗУП засобами наземної та повітряної розвідки;

$\lambda_{y p}$ - інтенсивність ураження Сі3 та Ооб ОС;

$\mu_{\text {вх розв }}-$ інтенсивність надходження вхідної інформації в систему управління від засобів розвідки;

$\mu_{\text {вх рез }}-$ інтенсивність надходження вхідної інформації в систему управління 3 результатами діяльності Сі3 та Ооб ОС;

$\mu_{\text {вих упр }}$ - інтенсивність видачі інформації системою управління з управлінськими рішеннями для Сi3 та Ооб ОC;

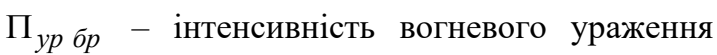
ВЗУ противника вогнем бригад (опдбр, омбр, омпбр, огшбр) ОТУ;

$\Pi_{y p ~ P B}$ - інтенсивність вогневого ураження ВЗУ противника вогнем ракетних військ ОТУ;

$\Pi_{y p A p}$ - інтенсивність вогневого ураження ВЗУ противника вогнем артилерії ОТУ;

$\Pi_{y p \text { Ав }}$ - інтенсивність вогневого ураження ВЗУ противника ударами армійської авіації та авіації ВПС;

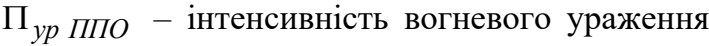
ВЗУ противника засобами ППО СВ та об'єктових ППО;

$\Pi_{y p ~ в x(в и x)}$ - інтенсивність (потрібна та реалізована) вогневого ураження противника;

$\Sigma$ - блок управління моделюванням та розрахунку очікуваних результатів оборонних дій.

Для оцінки рішень на оборону, що приймаються, доцільно розподіляти критерії за їх вагомими пріоритетами. Використання критерію буде визначатися конкретикою поставлених бойових завдань (декілька варіантів розрахунку пріоритетів за визначеними експертними оцінками). Обрані критерії оцінки сумарної ефективності ОС у сукупності визначають, на скільки створена оборона дозволяє зберегти сили і засоби ОТУ, що прикриваються.

За одним $з$ обраних критеріїв, з врахуванням пріоритету кожної складової ОС визначаються $j$-й варіант множини (більше двох) рішень зі своїми пріоритетами $W_{\text {вap }}$ :

$$
W_{j}^{M H}=\sum_{i=1}^{n} W_{\text {вар }} \cdot W_{c \kappa л_{i}} .
$$

Якщо позначити пріоритет кожного $i$-го критерію $W_{\kappa p_{i}}$, а пріоритет $j$-х варіантів рішень, що 
розглядаються за кожним критерієм, $W_{8 a p_{i j}}$, то за

формулою (1) можливо отримати значення глобального пріоритету кожного із $n$ варіантів рішень, які будуть визначати інтегральний критерій вибору раціонального рішення.

$$
W_{j}^{p i u}=\sum_{i=1}^{n} W_{\text {вар }} \cdot W_{\kappa p_{i}} .
$$

Під час планування, підготовки та ведення оборонних дій прогнозуються результати можливого ураження Сi3 та Ооб ОС з боку противника.

Для оцінки ефективності ОС ОТУ та ефективності дій противника, у відповідності зі схемою моделювання оборонних дій (рис. 1), визначені показники можна розрахувати 3 використанням відомих співвідношень між інтенсивністю процесів оборонних дій та втрат сторін. Крім того, потрібно брати до уваги можливості противника з ураження Ci3 та Ооб, що доцільно характеризувати системою імовірнісних, кількісних, просторових і часових показників. Цим вимогам задовольняє базовий набір показників [10-13]. Вони відповідають вимогам узгодженості показників між собою, повноті опису очікуваного результату оборонних дій та відчутності до реагування на зміни параметрів СО й умов обстановки. Оскільки замисел дій противника має достатньо високу початкову невизначеність, а результати боїв носять випадковий характер, то основні імовірнісні показники ефективності СО повинні відповідати наступним вимогам:

- відповідність меті та завданням СО;

- чіткий оперативно-тактичний та фізичний зміст;

- зручність обчислювання та використання;

- узгодженість (для системи показників ефективності оборонних дій різного рівня);

- чутливість до рішень на оборонні дії, що приймаються.

Згідно [10-13], основними розрахунковими показниками кількісної оцінки ефективності СО ОТУ доцільно вибрати такі:

- математичне сподівання (з урахуванням місця, часу і типів $(\kappa=1,2, \ldots, K)$ засобів сторін в абсолютних одиницях та відносно початкового $\left(N_{n_{\text {скл }}}\right)$ складу): кількості $\left(N_{y \kappa}\right)$ та частки ( $\left.\Delta N_{\text {скл }}=N_{y \kappa} / N_{n_{\text {скл }}}\right)$ уражених Сі3 СО (опдбр, омбр, омпбр, огшбр, РВ, Ар, Ав, ППО та ін.), які обороняються;

- $\left(N_{y p ~ n p}\right)$ - втрати ВЗУ противника від Сі3 СО OTУ;

- втрати Сі3 СО ОТУ, таких як $\left(n_{\text {знш розв }}\right)$,

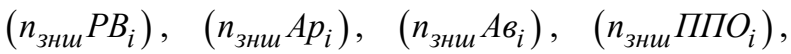

$\left(n_{\text {зни }} \sigma p_{i}\right)$,

де $б p_{i}$ - це опдбр, омбр, омпбр, огшбр та інші бригади $\mathrm{CB}$;

- втрати особового складу за родами військ та за рівнем ураження;

- витрачений ресурс: боєкомплект бригад i артилерії, ракет РВ, літако-вильотів авіації, зенітних керованих і авіаційних ракет та ін. в прийнятих одиницях вимірювання (за родами військ та ін.);

- кількість засобів противника, яку може відбити створена ОС ОТУ 3 врахуванням резерву $\left(N_{y \partial n p}\right)$.

За досвідом застосування військ [14-16] рівень загальних втрат, після яких противник змушений відмовлятися від продовження наступу (ударів), може складати біля 8-12\%. 3 досвіду військових операцій у Перській затоці [17] - цей рівень складав не більш як 1,5-2\%. Як показує досвід Югославського конфлікту та підтверджується подіями на сході країни, противник може зважитися на значно більший рівень втрат, який не обмежується вимогою збереження особового складу, а економічними розуміннями та прагненням не втратити дуже швидко свій військовий потенціал. Попередні оцінки показують, що у такому випадку рівень загальних втрат, на які буде здатний противник під час першої хвилі наступальних дій (ударі), може досягти 15-20\% його ВЗУ з поступовим зниженням цієї величини у наступних наступальних діях (ударах). Досвідом збройних конфліктів і війн останнього десятиріччя та подій на сході країни, а також науковими дослідженнями [14-17] встановлено, що:

- знищення або руйнування одиночного елементу зі складу Сі3 та Ооб СО досягається при імовірності їхньої поразки не менш 90 \%;

- знищення групових елементів із складу Сi3 та Ооб СО досягається при математичному сподіванні відносного числа уражених елементів СО або частини площі об'єкту оборони, що надійно уражається (не менше 50 \%);

- придушення СО, тобто нанесення ій такого збитку (пошкоджень) та створення для неї таких умов, при яких тимчасово позбавляються боєздатності вогневі засоби опору або обмежується управління, досягається математичним сподіванням відносного числа уражених елементів зі складу С3 СО або частини площі Ооб, що надійно уражається (не менше 25-30\%).

Імовірність $P_{y p}$ ураження типовим засобом вогневого ураження противника наземного об'єкта зі складу $\mathrm{Ci} 3 \mathrm{CO}$, розміри якого менше радіуса ураження бойовим зарядом, який застосовується, $R_{y p}$ (об’єкт - точковий) визначається як імовірність влучення в коло характерного радіуса з урахуванням 
технічної надійності засобів доставки боєприпасів до цілі $P_{m н}$ і можливості подолання СО $P_{\text {nод }}$ :

$$
P_{y p}=\left[1-\exp \left(\frac{r^{2} \cdot R^{2} y p}{E_{x} \cdot E_{y}}\right)\right] \cdot P_{m H} \cdot P_{\text {nод }}
$$

де $r=0,476936$;

$E_{x}, E_{y}-$ серединні відхилення засобу доставки боєприпасів від точки прицілювання (місця розташування ВЗУ противника) за дальністю та у бічному напрямку відповідно. Вони залежать:

- від похибки визначення взаємного положення наземного об'єкта зі складу Сі3 та Ооб ОС, що уражається;

- від засобу доставки боєприпасів до цілі;

- від характеристик системи наведення боєприпасів на ціль;

- від похибок розпорядження (цілевказіння);

- від помилок виведення ВЗУ противника у район цілі.

Також доцільно розрахувати (спрогнозувати) імовірність дій ВЗУ противника щодо ураження елементів зі складу Сi3 та Ооб ОС $P_{y p}$ ел заданим нарядом засобів ураження $H_{y p}$ з урахуванням бойової стійкості елементів (опорних пунктів, районів оборони, артилерійських батарей, комплексів РВ, ЗРК, авіації й т.ін.) зі складу Сі3 та Ооб ОС (тобто імовірності його знищення ВЗУ противника до рубежу виконання завдання) $P_{H_{y p}}$ може бути визначена за формулою:

$$
P_{y p_{\text {ел }}}=\left[1-\left(1-P_{y p}\right)^{n}\right] \cdot P_{H_{y p}} .
$$

Зазначений вираз дозволяти одержати оцінку бойових нарядів ВЗУ противника для ураження елементів зі складу Сi3 та Ооб ОС:

$$
N=\frac{\ln \left(1-P_{y p_{e л}}\right) / P_{H_{y p}}}{l_{n}\left(1-P_{y p}\right)} .
$$

При $P_{H_{y p}}=1-P_{y p}$ і $P_{y p}<>0$ одержується бойовий наряд ВЗУ противника для ураження Сi3 та Ооб ОС ОТУ. При цьому, математичне сподівання імовірнісних і середніх втрат військової техніки й озброєння (ВТО) Сi3 та Ооб ОС у припущенні, що втрати завдають усі атакуючі ВЗУ противника усім елементам ОС, а втрати, що нанесені одним ВЗУ противника не залежать від втрат, що наносить інший ВЗУ противника (рис. 2), можна знайти за формулою:

$$
M_{y}=\sum_{j=1}^{m} \sum_{r=1}^{k} B_{j r} \cdot Q_{j r} \cdot \prod_{i=1}^{n}\left(1-P_{i j} \cdot A_{i j r}\right) \cdot X_{i j} \cdot
$$

Аналогічно розглянемо модель ураження ВЗУ противника. Об'єктом моделювання є процес ура- ження ВЗУ противника в наступальних діях без застосування зброї масового ураження.

Мета процесу ураження полягає в нанесенні ВЗУ противника ураження заданих втрат, які в результаті призводять до часткової або повної втрати противником можливості функціонування за призначенням.

Градацію ступенів ураження ВЗУ противника введемо відповідно до необхідних працевитрат на відновлення уражених ВЗУ противника, таких як слабкі, середні, сильні ступені ураження та повне знищення.

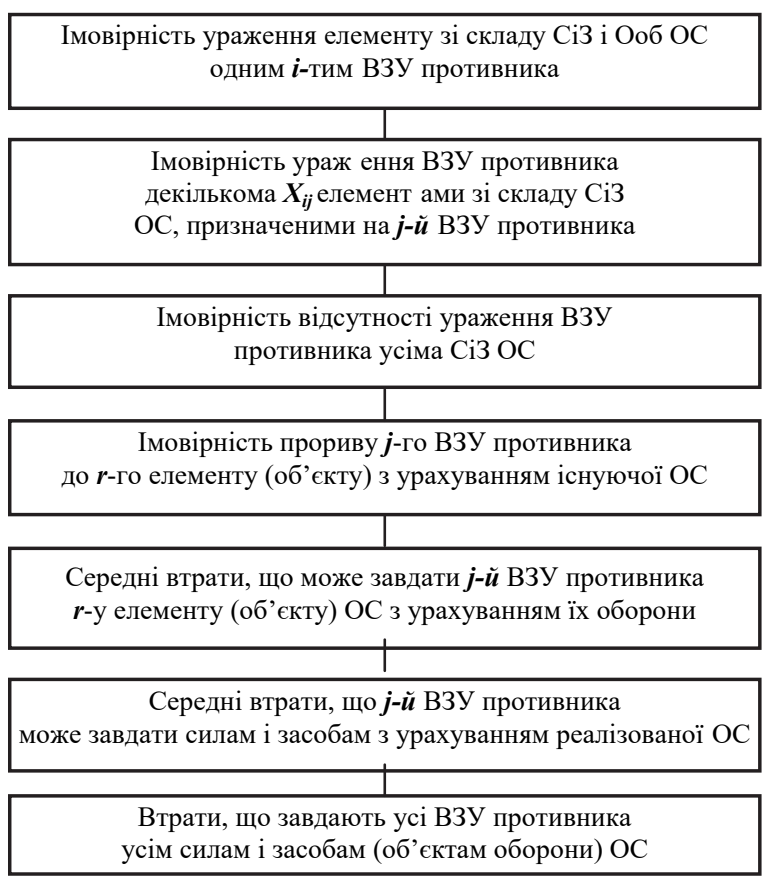

Рис. 2. Перелік показників оцінки ефективності ОС

Iз рис. 2:

$r=\{1,2, \ldots, k\}-$ порядковий номер елементу зі складу Сі3 та Ооб ОС що обороняється;

$i=\{1,2, \ldots, n\}-$ порядковий номер елементу зі складу Сі3 та Ооб ОС;

$j=\{1,2, \ldots, m\}-$ порядковий номер ВЗУ противника;

$P_{i j}$ - умовна можливість ураження $j$-го ВЗУ противника $i$-м елементом зі складу Сi3 ОС, за умови, що цей ВЗУ увійде в зону ураження та реалізуються умови балансу між готовністю до обстрілами за часом;

$A_{i j r}$ - можливість того, що ВЗУ противника, що атакує $r$-й елемент зі складу Сі3 та Ооб ОС, увійде в зону ураження $i$-го елементу зі складу Сi3 OC;

$X_{i j}$ - кількість елементів зі складу Сі3 та Ооб OC, що призначені для ураження $j$-го ВЗУ противника; 
$Q_{j r}$ - імовірність того, що $j$-й ВЗУ противника атакує $r$-й елемент зі складу Сі3 та Ооб ОС;

$B_{j r}$ - середні втрати, що завдає $r$-му елементу зі складу Сі3 та Ооб ОС $j$-й ВЗУ противника.

Під час нанесення ушкоджень ВЗУ як правило, виникає супутнє ураження особового складу, який застосовує ВЗУ у ході наступальних дій. Математичне сподівання втрат серед особового складу пов'язано зі ступенем ушкоджень ВЗУ й може скласти від 5 до $50 \%$ особового складу, відповідно для слабкого, середнього, сильного та повного ступеня ушкодження пошкоджених ВЗУ.

Метою моделювання є:

- визначення ступеня ураження ВЗУ противника, що досягається залежно від умов ураження (від кількості й типу боєприпасів, наряду на ВЗУ, що уражаються й т. ін. );

- визначення закону розподілу кількості елементів ВЗУ, які уражаються, за ступенями ураження, що необхідно для організації ефективної ОС та визначення можливих втрат серед особового складу.

При цьому показники якості ураження вибираються такими:

- можливість нанесення ВЗУ противника заданого ступеня ушкоджень;

- математичне сподівання числа уражених елементів ВЗУ противника за ступенями ураження;

- дисперсія числа уражених наступальних елементів противника.

Критеріями оцінки ефективності процесу ураження противника можуть бути:

- максимум нанесених втрат;

- нанесення розміру втрат не менше заданого.

Доцільний ступінь деталізації моделювання проводиться до елементу вогневих засобів противника, що уражається, й до стану ступеню його ураження. Довірча імовірність для результатів моделювання не повинна бути гірше ніж 0,95 ; довірчий інтервал - не більш $1 \%$ від оцінюваного розміру. Швидкість виконання розрахунків АСОП на ЕОМ повинна забезпечувати час моделювання не більш одиниць секунд, тому що модель ураження ВЗУ противника $\epsilon$ частиною штабної моделі, яка дозволяє виробити пропозиції щодо рішення на оборону. Об'єкт ураження, як правило, складається 3 груп елементів, кожна 3 яких відрізняється за призначенням й стійкістю до вражаючих факторів боєприпасів. Противник, що прорвався через смугу оборони, може застосувати осколково-фугасні, запальні та боєприпаси об'ємного вибуху, які можуть різнитися в точності систем наведення, мати різноманітну вагу й тип вибухової речовини. Для ураження різноманітних елементів ВЗУ противника можуть використовуватися різноманітні точки прицілювання. Фізичний процес ураження пов'язаний із різночасною доставкою й підривом боєприпасів на території об'єктів ураження. У складі гіпотез і допущень щодо характеру процесу, який аналізується, можна виділити такі:

- елементи ВЗУ противника, що уражаються i, які об'єднані в одну групу, однакові з погляду стійкості до вражаючих факторів;

- координати точки підриву боєприпасів розподілені за нормальним законом відносно точки прицілювання;

- за час застосування боєприпасів кількість елементів ВЗУ противника, що уражається, не змінюється;

- фактор запального впливу боєприпасів при ураженні елементів Сi3 та Ооб ОС є менше істотним, ніж осколковий й фугасний вплив;

- радіус поразки $r$ при вибуху боєприпасів пов'язаний із вагою вибухової речовини $q$ за формулою Садовського [18]:

$$
r=(k \cdot q)^{1 / n},
$$

де $k$ - коефіцієнт, що залежить від типу боєприпасів і уразливості елементів ВЗУ противника;

$n=1,5, \ldots, 3$ - показник ступеня, що залежить від умов застосування боєприпасів. Для більшості умов підриву боєприпасів у поверхні землі $n=2$.

Отже, якщо оборона за розглянутими показниками ефективності (відсоток знищених ВЗУ противника) дозволяє нанести суттєвих втрат противнику, після яких той відмовляється від продовження бойових дій (наступу), вона може вважатися достатньою або сильною. Якщо створена $\mathrm{CO}$ не здатна до цього, вона є недостатньою або слабкою.

Час розвитку процесу ураження $\epsilon$ величиною “пасивною”, що фіксує лише моменти, у які наступає то чи інше руйнування або відповідна ступінь ушкодження. Якщо кількість елементів об'єкта, що уражається, за час бою не убуває, то розміри й вага ушкоджень не залежать від того, у які моменти та на якій хвилині бою відбувся підрив боєприпасів у районі об'єкта, що уражається. Ступінь ушкоджень елементів об'єкта визначається розміром вражаючого заряду, відстанню до точки підриву й залежить від стійкості елементів об'єкта до вражаючих факторів вибуху боєприпасів. Залежно від промаху $r$, той же самий заряд може призвести до різноманітних ступенів поразки. Тому, доцільно знайти щільність розподілу заряду $f(q)$, що уражає, для слабкого ступеня ушкодження об'єкта, з огляду на випадковий характер промаху під час доставки боєприпасів.

3 території стрільби відомо, що щільність розподілу випадкової величини промаху (як відстані від точки підриву боєприпасів до точки прицілювання) описується законом Релея: 


$$
f(r)=\frac{r}{\delta} \cdot \exp \left(-\frac{r^{2}}{2 \delta^{2}}\right),
$$

де $\delta$ - середнє квадратичне відхилення розміру промаху.

У свою чергу, радіус зони руйнування та ушкоджень (припустимий промах) $r$ і вага $q$ вибухової речовини боєприпасів пов'язані співвідношенням (3).

Отже, закон розподілу вражаючого заряду $q$ розраховується як закон розподілу функції випадкового розміру $r$, тобто:

$$
f(q)=f(r) \cdot r^{2}(q)=L_{1} \cdot \exp \left(-L_{1} \cdot q\right) .
$$

Деякі багатоелементні Сі3 ОС ОТУ, такі як артилерійські батареї, установки $\mathrm{PB}$, взводні й ротні опорні пункти, позиції ЗРК, аеродроми й т.ін. являють для ВЗУ противника групову компактну ціль. Тому, під час оцінки результатів майбутнього ураження таких об'єктів необхідно враховувати їхній бойовий порядок. Один із можливих підходів до побудови таких моделей полягає у розгляді двох станів кожного елемента - він уражений або не уражений. Передбачається, що в загальній зоні уразливості об'єкта можуть бути області $3 j$-кратним перекриттям зон уразливості його окремих елементів. При влученні боєприпасів у таку область можливе ураження усіх $j$ елементів. Тоді у якості величини, що характеризує розташування на місцевості елементів об'єкта, що уражається, може бути прийнятий вектор шарів зони уразливості $D=\{d l, \ldots, d m\}$, де $m-$ максимальне число елементів, що уражаються 3 однієї точки підриву боєприпасів, а $d j-$ площі $3 j$ кратним перекриттям зон уразливості окремих елементів. У цьому випадку ураження об'єкта ОС, що включає $N$ елементів, розглядається як процес 3 $N+1$ можливими станами, кожний з яких $\mathrm{Si}$ відповідає ураженню рівно $i$ елементів.

Процес ураження розвивається під дією сумарного пуассонівського потоку (одинарного потоку однорідних подій) заряду $q$, що уражає, має параметр потоку ураження $L$. При цьому сумарний потік $\epsilon$ суперпозицією незалежних парціальних потоків, кожний із яких характеризується постійним числом $j$ елементів, що уражається, й має параметр $L j$ показового розподілу вражаючого заряду (3), пропорційний розміру $d j$ :

$$
L j=L \cdot d j, \cdots j=\{1, m\} .
$$

Таким чином, модель процесу ураження елементу Сі3 та Ооб ОС, що включає $N$ рознесених елементів на місцевості, які утворюють групову компактну ціль, може бути подана неординарною схемою ураження з вектором неординарності $\{d l, \ldots, d m\}$.
Розвиток процесів у моделі описується системою диференціальних рівнянь Колмогорова [19], що має аналітичне рішення. Під час практичного використання моделі виникає необхідність у визначенні сумарного приведеного заряду $Q$, що впливає на об'єкти ОС та значень оцінок інтенсивності $L$ вражаючих потоків, що впливають на Сі3 та Ооб ОС.

3 метою визначення сумарного приведеного заряду, що впливає на елементи Сi3 та Ооб ОС, використовують коефіцієнти еквівалентності між боєприпасами різноманітних типів. Критерієм еквівалентності боєприпасів може бути прийнята можливість нанесення елементу Сi3 та Ооб ОС, ураження не нижче заданого. Значення коефіцієнта еквівалентності $K_{\text {екв }}$ у загальному випадку є функцією потужності порівнюваних боєприпасів $Q$, а також точності їхньої доставки, варіанта розміщення елемента Сi3 та Ооб СО, що уражається, на місцевості й стійкості його до вражаючих факторів. Для спрощення процесу обчислень існують спеціальні таблиці коефіцієнтів еквівалентності боєприпасів різноманітного типу.

Наступним кроком доцільно розрахувати розмір сумарного приведеного заряду при відомих коефіцієнтах еквівалентності окремих зарядів, що визначається за формулою:

$$
Q_{\text {сум }}=\sum_{i=1}^{r}\left(C_{i} \cdot K_{\text {екв }} \cdot Q_{i}\right),
$$

де $r$ - кількість типів боєприпасів, застосовуваних противником;

$C_{i}$ - кількість боєприпасів $i$-го типу;

$K_{\text {екв }}$ - коефіцієнт еквівалентності боєприпасів типу $i$;

$Q_{i}$ - потужність боєприпасів типу $i$.

Для практичного використання моделі ураження необхідно також визначити значення інтенсивності $L$ ураження елементів Сі3 та Ооб ОС. Ураження відкрито розташованих Сі3 та Ооб ОС визначається фугасною, осколковою й запальною дією звичайних боєприпасів. На практиці важко виділити й спрогнозувати усі причини й умови, що визначають основний вражаючий фактор впливу вибуху на той або інший елемент Сi3 та Ооб ОС. Так, наприклад, запальна дія виявляється як правило, при ураженні паливно-мастильних матеріалів і в даному випадку може не розглядатися. Вплив інших факторів на Сi3 та Ооб ОС необхідно враховувати спільно. Тому, потік уражень складається 3 потоку фугасної та осколкової дії. При цьому критерієм ураження елементів Сi3 та Ооб ОС від фугасної дії боєприпасів $є$ граничне значення розміру питомого імпульсу енергії вибуху $q_{\phi}$, що пов'язаний з радіусом ураження елементів Сі3 та Ооб ОС $r$ і вагою $q$ вибухової 
речовини. Тому, інтенсивність вражаючого потоку фугасної дії $L_{\phi д}$ знаходиться як величина зворотнопропорціональна питомому імпульсу енергії вибуху.

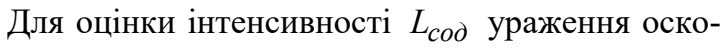
лковою дією боєприпасів, вхідною інформацією є середня кількість осколків для ураження елемента Ci3 та Ооб ОС, середня площа бічної поверхні елемента та співвідношення між потужністю боєприпасів, вагою й швидкістю розльоту осколків. Інтенсивність спільної фугасної й осколкової вражаючої дії визначається сумою інтенсивності:

$$
L=L_{\phi \partial}+L_{c o \partial} .
$$

Для підвищення оперативності оцінок результатів ураження під час планування оборонних дій, на основі аналітичних виражень моделі ураження Сi3 та Ооб ОС можуть бути розраховані відповідні аналітичні залежності відносних значень математичного сподівання кількості елементів типових $\mathrm{Ci} 3$ та Ооб СО, що уражаються, (у відсотках) від сумарного приведеного заряду, які мають вигляд:

$$
M_{i} \frac{\left(B \cdot Q_{c y M}\right)}{i !} \cdot \exp \left(-B \cdot Q_{c y M}\right)
$$

де $Q_{c y м}$ - розмір сумарного приведеного заряду;

$B$ - коефіцієнт апроксимації (варіант $B=\sim$ );

$i$ - ступінь ураження (0 - немає ураження, 1 - слабкі ураження, 2 - середні, 3 - сильні, 4 - повне ураження).

Таким чином, спрощення моделі процесу ураження Сi3 та Ооб ОС у випадку уявлення його залежно від сумарного приведеного заряду, свідчить на користь коректності використаних принципів формалізації й дозволяє одержати повний опис характеристик очікуваних випадкових результатів процесу, недосяжних при традиційних способах формалізації.

Одночасно модель забезпечує одержання оцінок з одиничним значенням довірчої імовірності та 3 нульовим значенням довірчого інтервалу при однократному прогоні моделі. Застосування апроксимуючих виражень типу (4) додатково збільшує швидкість розрахунків, забезпечуючи їхню високу оперативність.

Одержані за допомогою моделі оцінки очікуваних результатів ураження за ступенями ушкодження елементів Сі3 та Ооб ОС є вхідною інформацією для моделювання й розробки пропозицій для рішення на оборону та подальшого планування заходів щодо відновлення ОС.

Проаналізуємо показники ефективності ОС, які будуть покладені в основі вибору пропозицій для рішення на оборону (табл. 1).
Таблиця 1

Значення пріоритетів (приклад) основних критеріїв під час моделювання оборонних дій в обраному варіанті побудови ОС ОТУ на $i$-му змодельованому оперативно-тактичному напрямку, за якими

\begin{tabular}{|c|c|c|c|}
\hline $\begin{array}{c}\text { № } \\
\text { пунк- } \\
\text { ту } \\
\end{array}$ & Назва, формульне позначення & $\begin{array}{c}\text { Значення } \\
\text { пріоритету } \\
W_{k p} \\
\end{array}$ & $\begin{array}{c}\text { Інші } \\
\text { параметри }\end{array}$ \\
\hline 1 & $\begin{array}{l}\text { Ефективність ОС не нижче заданої } \\
E_{C O}>E_{C O} \text { зад }\end{array}$ & 0,208 & \multirow[t]{8}{*}{$\begin{array}{l}\lambda_{\max }=8,571 \\
\mathrm{BY}=0,058\end{array}$} \\
\hline 2 & 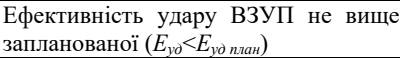 & 0,027 & \\
\hline 3 & $\begin{array}{l}\text { Імовірність збереження Сі3 та Ооб } \\
\text { ОС не нижче заданої }\left(P_{3 \hat{}}>P_{36} \text { зад }\right)\end{array}$ & 0,265 & \\
\hline 4 & $\begin{array}{l}\text { Збереження об'єктів прикриття } \\
\text { даного типу не менше заданої кілько- } \\
\text { сті }\left(N_{3 \sigma i}>N_{36 \text { зад } i)}\right.\end{array}$ & 0,130 & \\
\hline 5 & $\begin{array}{l}\text { Досягнення } \quad \text { заданого } \\
\text { відвернутих втрат }\left(B_{6}>B_{6 з \text { зад }}\right)\end{array}$ & 0,199 & \\
\hline 6 & $\begin{array}{l}\text { Коефіцієнт статичного співвідношен- } \\
\text { ня більше заданого }\left(K_{c}>K_{c \text { зад }}\right)\end{array}$ & 0,028 & \\
\hline 7 & $\begin{array}{l}\text { Коефіцієнт динамічного співвідно- } \\
\text { шення } K_{\partial c}>1\end{array}$ & 0,075 & \\
\hline 8 & 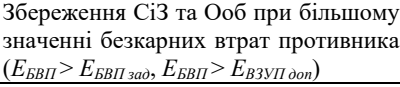 & 0,068 & \\
\hline
\end{tabular}

обираються пропозиції для рішення на оборону

Перший показник - це ефективність $\left(E_{c o}\right)$ відбиття Сі3 ОС наступу ВЗУ противника - частковий показник, який визначає сумарну ефективність дій Сі3 CO:

$$
E_{o c}=E_{б p}+E_{P B}+E_{A p}+E_{A в}+E_{П П О} .
$$

Ефективність відбиття наступу ВЗУ противника характеризує відсоток сумарних втрат, яких зазнав противник за час бойових дій.

Другий показник - це ефективність оборонних дій Сi3 $\left(E_{б p(P B, A p, A в, П П О, \ldots)}\right)$ ОС. Цей показник включає відношення кількості ВЗУ противника, що знищені Сі3 ОС ОТУ, до кількості ВЗУ противника в наступі (ударі):

$$
E_{б p(P B, A p, A в, \Pi \Pi O, \ldots .)}=\frac{N_{3 н} б p(P B, A p, A в, \Pi \Pi O, \ldots) n p}{N_{n p}} .
$$

Ефективність дій Сi3 ОС характеризує відсоток знищених ВЗУ противника відповідними засобами, тобто їхній вклад у вирішення завдань оборони, що дозволяє мати судження щодо якості вирішення завдань відповідними Сi3 ОС. За фізичним змістом ефективність ОС носить характер середньостатистичної імовірності ураження одного елементу (засобу) ВЗУ противника під час бойових дій. Аналогічно в табл. 2 методом аналізу ієрархій [20] визначена пріоритетність пропозицій щодо складових загальної ефективності ОС.

Третій показник - це ефективність застосування забезпечувальних (підрозділи матеріальнотехнічного постачання) та спеціальних підрозділів повітряної, радіолокаційної, радіотехнічної та військової розвідки (у подальшому - засобів розвідки (3/розв)), може бути оцінений як середньозважений внесок таких підрозділів до загальної ефективності OC OTY. 
Таблиця 2

Значення пріоритетів (приклад) складових загальної ефективності в обраному варіанті побудови ОС

ОТУ, при моделюванні оборонних дій на $i$-му змодельованому оперативно-тактичному напрямку, які визначатимуть пропозиції до рішення на оборону

\begin{tabular}{|c|c|c|c|}
\hline $\begin{array}{c}\text { № } \\
\text { пункту }\end{array}$ & $\begin{array}{c}\text { Назва, } \\
\text { формульне } \\
\text { позначення }\end{array}$ & $\begin{array}{c}\text { Значення } \\
\text { пріоритету } \\
W_{63} \\
\end{array}$ & $\begin{array}{c}\text { Інші } \\
\text { параметри }\end{array}$ \\
\hline 1 & $\begin{array}{c}\text { Ефективність } \\
E_{\tilde{\sigma}}\end{array}$ & 0,785 & \multirow{3}{*}{$\begin{array}{l}\lambda_{\max }=3,080 \\
\mathrm{BV}=0,069 .\end{array}$} \\
\hline 2 & $\begin{array}{c}\text { Ефективність } \\
E_{P B i A} \\
\end{array}$ & 0,149 & \\
\hline 3 & 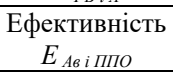 & 0,066 & \\
\hline
\end{tabular}

Наприклад, ефективність засобів розвідки, як складової ОС, за таким підходом може бути оцінена співвідношенням:

$$
E_{\text {в/ розв }}=\frac{E_{O C}-E_{0}}{E_{O C}},
$$

де $E_{O C}$ - ефективність ОС у випадку, коли у ході оборонних дій на пунктах управління всіх рівнів застосовується інформація від усіх підрозділів, які здійснюють розвідку;

$E_{0}$ - ефективність дій “активних” Сі3 ОС, коли застосовується інформація тільки від своїх засобів розвідки.

Для звичайних умов організації та ведення оборони, приріст іiї ефективності завдяки роботі підрозділів, які здійснюють розвідку, насамперед, визначається імовірністю своєчасного виявлення наземних та повітряних цілей противника, що, в свою чергу, забезпечується злагодженою системою розвідки. Задана імовірність цілей $\left(\mathrm{P}_{\text {виявл } з а д ~}\right)$ на конкретному напрямку, в конкретних умовах обстановки визначається кратністю перекриття так званих зон виявлення засобами розвідки $\left(n_{\Pi_{\text {зон }} \text { виявл }}\right)$ та імовірністю виявлення цілей противника окремими засобами (оптичними приладами, БПЛА, станціями РЛС або РТР й т.ін.) розвідки $\left(P_{i}\right)$. Тоді коефіцієнт перекриття розраховується за формулою:

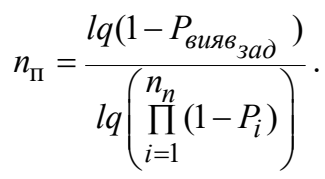

При цьому потрібний рубіж (відстань) виявлення цілей противника та своєчасне надання бойової інформації розраховується за формулою:

$$
T_{\text {nотр }}=Д_{\partial}+V_{u} t_{K \Pi_{i}}+V_{u} t_{\text {вз }}+V_{u} T_{K \Pi_{\Sigma}{ }_{3 / \text { розв }},}
$$

де $Д_{\partial}-$ встановлений рубіж (відстань) виконання бойового завдання (вогневого ураження) підрозділами та частинами, що входять до складу ОС ОТУ;

$V_{u}$ - розрахункова швидкість руху (наближен- ня) наземного противника або польоту повітряної цілі противника;

$$
t_{\kappa \Pi_{i}} \text { - час, який } i \text {-й КП частини (КСП підроз- }
$$
ділу) зі складу ОС ОТУ витрачає з моменту отримання даних про противника до надання розпорядження (цілевказіння) підлеглим підрозділам на їх знищення;

$t_{83}-$ час виконання бойового завдання частинами та підрозділами зі складу ОС ОТУ;

$T_{K \Pi_{\Sigma} \text { з/ розв }}$ - сумарний робочий час усіх КП частини й підрозділів, що залучені до добування, обробки та надання розвідувальної інформації.

Пріоритетність систем забезпечення згідно [7; 20] представлені в табл. 3.

Четвертий показник - це статичне співвідношення сил сторін $K_{c}$, яке відображає відношення сумарної зваженої за імовірністю знищення ВЗУ противника та кількістю задіяних Сі3 ОС до зваженої за оперативно-тактичною важливістю кількості ВЗУ противника, задіяних в наступальних діях або ударі (за діапазонами відстаней дій ВЗУ противника та можливостями дій Ci3 за напрямками та у цілому за OC):

Таблиця 3

Значення пріоритетів (приклад) військ забезпечення,

\begin{tabular}{|c|c|c|c|}
\hline $\begin{array}{c}\text { № } \\
\text { пункту }\end{array}$ & $\begin{array}{c}\text { Назва, } \\
\text { формульне позначення }\end{array}$ & $\begin{array}{c}\text { Значення } \\
\text { пріоритету } \\
W_{\text {збn }}\end{array}$ & $\begin{array}{c}\text { Інші } \\
\text { пара- } \\
\text { метри }\end{array}$ \\
\hline 1 & $\begin{array}{l}\text { Система } \\
\text { розвідки }\end{array}$ & 0,102 & \multirow{6}{*}{$\begin{array}{l}\lambda_{\max }=5,091 \\
B У=0,02\end{array}$} \\
\hline 2 & Система РЛР & 0,176 & \\
\hline 3 & Система РЕБ & 0,211 & \\
\hline 4 & Система РТР & 0,094 & \\
\hline 5 & $\begin{array}{l}\text { Система технічного } \\
\text { забезпечення }\end{array}$ & 0,129 & \\
\hline 6 & $\begin{array}{l}\text { Система тилового } \\
\text { забезпечення }\end{array}$ & 0,088 & \\
\hline
\end{tabular}
які визначатимуть пропозиції щодо рішення на оборону, при моделюванні оборонних дій на $i$-му змодельованому оперативно-тактичному напрямку

$$
\begin{aligned}
& K_{c}=\frac{M_{n i \partial p б p}+M_{\kappa P B}+M_{A p}+M_{A в}+M_{\Pi \Pi O}}{N_{n p}} ; \\
& M_{\text {niдp бp }}=N_{\text {niдp бp }} \cdot P_{\text {niдp бp }} \cdot U_{n p} \text {; } \\
& M_{\text {бат Ap }}=N_{\text {бат Ap }} \cdot P_{\text {бат Ap }} \cdot U_{n p} \text {; } \\
& M_{\kappa P B}=N_{\kappa P B} \cdot P_{\kappa P B} \cdot U_{n p} ; \\
& M_{A B}=N_{A B} \cdot P_{A B} \cdot U_{n p} ; \\
& M_{\text {ППО }}=N_{\text {ППО }} \cdot P_{\text {ППО }} \cdot U_{A B n p},
\end{aligned}
$$

де $N_{n p}$ - зважена за оперативно-тактичною важливістю кількість ВЗУ противника в наступі;

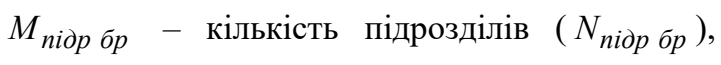

зважена за апріорною середньостатистичною імовірністю знищення підрозділу противника одним 
підрозділом бригади $\left(P_{\text {niдp бр }}\right)$ з урахуванням кількості боїв, що можуть ним проводитись за час відбиття удару ВЗУ противника ( $\left.U_{n p}\right)$;

$M_{\kappa P B}$ - кількість комплексів РВ $\left(N_{\kappa P B}\right)$, зважена за апріорною середньостатистичною імовірністю знищення об'єкту противника одним комплексом $\left(P_{\kappa P B}\right)$ з урахуванням кількості стрільб, що можуть ним проводитись за час відбиття удару ВЗУ противника ( $\left.U_{n p}\right)$;

$M_{\text {бат Ap }}$ - кількість артилерійських батарей ( $N_{\text {бат } A p}$ ), зважена за апріорною середньостатистичною імовірністю знищення цілі противника одною

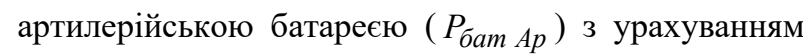
кількості стрільб, що можуть нею проводитись за час відбиття удару ВЗУ противника $\left(U_{n p}\right)$;

$M_{A в}$ - кількість, літаків (вертольотів) $\left(N_{A в}\right)$, зважена за апріорною середньостатистичною імовірністю знищення ВЗУ противника одним літаком $\left(P_{A в}\right)$ з урахуванням кількості боїв, що можуть ним проводитись за час відбиття удару ВЗУ противника $\left(U_{n p}\right)$;

$M_{\text {ППО }}$ - кількість ЗРК (інших засобів) ППО $\left(N_{\text {ППО }}\right)$, які забезпечують безпосереднє прикриття Ci3 та Ооб ОС, зважена за апріорною середньостатистичною імовірністю знищення повітряної цілі противника одним засобом (наприклад, ЗРК) ППО $\left(P_{П П О}\right)$ з урахуванням кількості повітряних цілей, що може він обстрілювати за час відбиття удару авіації противника ( $\left.U_{A в n p}\right)$.

Статичне співвідношення сил сторін $K_{c}$ характеризує початковий стан протидіючих сторін. Якщо статичне співвідношення сил досягає одиниці, сили сторін до початку бойових дій можна вважати приблизно однаковими. Проте у ході оборонних дій як ВЗУ противника, так і частини та підрозділи ОС несуть втрати, завдяки чому, вихідне статичне співвідношення сил змінюється. Щоб знати на якому боці буде перевага, треба використати уже розглянутий вище показник, який відображає динаміку оборонних дій, тобто динамічне співвідношення сил сторін $K_{\partial c}$. Цей показник оцінює відношення середньої швидкості втрат ВЗУ противника до середньої швидкості втрат $\mathrm{Ci} 3 \mathrm{OC}$, а також дозволяє визначити, хто раніше втратить можливість для подальшого ведення бойових дій.

Динамічне співвідношення сил обчислюють 3 застосуванням моделей динаміки бойових дій для очікуваних оперативно-тактичних умов відбиття ударів ВЗУ противника за конкретним варіантом обраного угруповання Сi3 ОС. Якщо середня швид- кість втрат сторін відшукується на однаковому часовому інтервалі (наприклад, за час наступу або удару), то математичний вираз для розрахунку показника може бути зведений до відношення зваженої за оперативно-тактичною важливістю частки знищених ВЗУ противника до рівня (частки) втрат Сi3 ОС, зрівноваженого за середньою кількістю ВЗУ противника, які вони здатні знищити у ході оборонних дій. Тобто:

$$
\begin{aligned}
& \mathrm{K}_{д C}=\frac{\delta_{y p n p}}{\delta o c}, \text { тоді } \delta_{y p n p}=\frac{N_{y p n p}}{N_{n p}} ; \\
& \delta_{y p ~ o c}=\frac{M_{n б p}+M_{n Р B}+M_{n A p}+M_{n A в}+M_{n \text { ППО }}}{M_{б p}+M_{P B}+M_{A p}+M_{A в}+M_{П П О}} ; \\
& N_{y p}=M_{б p}+M_{P B_{n p}}+M_{A p_{n p}}+M_{A \beta_{n p}} M_{\Pi \Pi O_{n p}} ;
\end{aligned}
$$

де $M_{б p_{n p}}\left(M_{P B_{n p}}, M_{A p_{n p}}, M_{A \beta_{n p}}, M_{\Pi \Pi O_{n p}}\right)$ - оцінка кількості ВЗУ противника, що знищені Сі3 ОС;

$$
M_{n_{б p}}\left(M_{n_{P B}}, M_{n_{A}}, M_{n_{A в}}, M_{n_{\Pi \Pi O}}\right) \quad \text { - оцінка }
$$

кількості знищених Сi3 та Ооб ОС. Динамічне співвідношення сил сторін характеризує, як швидко і в який бік змінюється співвідношення сил у ході бойових дій. Якщо показник більше від одиниці, то співвідношення змінюватиметься на користь Сі3 ОС, якщо менше - на користь ВЗУ противника (табл. 4).

Таблиця 4

\begin{tabular}{|c|c|c|c|}
\hline $\begin{array}{l}\text { № } \\
\text { п/П }\end{array}$ & $\begin{array}{c}\text { Назва, } \\
\text { формульне } \\
\text { позначення }\end{array}$ & $\begin{array}{c}\text { Значення } \\
\text { пріоритету } \\
W_{\text {скл } i}\end{array}$ & $\begin{array}{c}\text { Інші } \\
\text { параметри }\end{array}$ \\
\hline 1 & $\begin{array}{l}\text { ОС бр (опдбр, омбр, } \\
\text { омпбр та огшбр) }\end{array}$ & 0,345 & \multirow{5}{*}{$\begin{array}{l}\lambda_{\max }=8,782 \\
\mathrm{BY}=0,079\end{array}$} \\
\hline 2 & Система РВ & 0,133 & \\
\hline 3 & Система Ар & 0,09 & \\
\hline 4 & Система Ав & 0,107 & \\
\hline 5 & Система ППО & 0,145 & \\
\hline 6 & Система РЕБ & 0,065 & \\
\hline 7 & Система РТР & 0,025 & \\
\hline 8 & $\begin{array}{l}\text { Система технічного } \\
\text { забезпечення }\end{array}$ & 0,051 & \\
\hline 9 & $\begin{array}{l}\text { Система тилового } \\
\text { забезпечення }\end{array}$ & 0,038 & \\
\hline
\end{tabular}

Пріоритети загальної взаємозалежності (приклад) сил і засобів ОС для вибору пропозицій щодо рішення на оборону

Тому кращою є така ОС, яка за час ведення оборонних дій забезпечує збільшення цього показника від одиниці.

П'ятий показник - це середньозважена за часом імовірність збереження об'єктів (за їх типами) (рис. 3).

Якщо під час моделювання бойових дій (час удару ВЗУ противника $-T_{y \partial}$ ) аналізувати залеж-

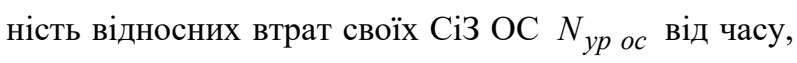
можливо отримати середньозважену імовірність 
$P_{y p ~ o c ~}$ їх ураження (рис. 4) наступною формулою:

$$
P_{y p o c}\left(t, N_{y p o c}\right)=\frac{1}{T_{y \partial} \cdot N_{y p o c}} \int_{0}^{T_{y \partial}} F\left(t, N_{y p c c}\right) d t .
$$

Загальну площу під функцією $F\left(t, N_{y p}\right.$ oc $)$ можна знайти методами чисельного інтегрування (рис. 3) за формулою:

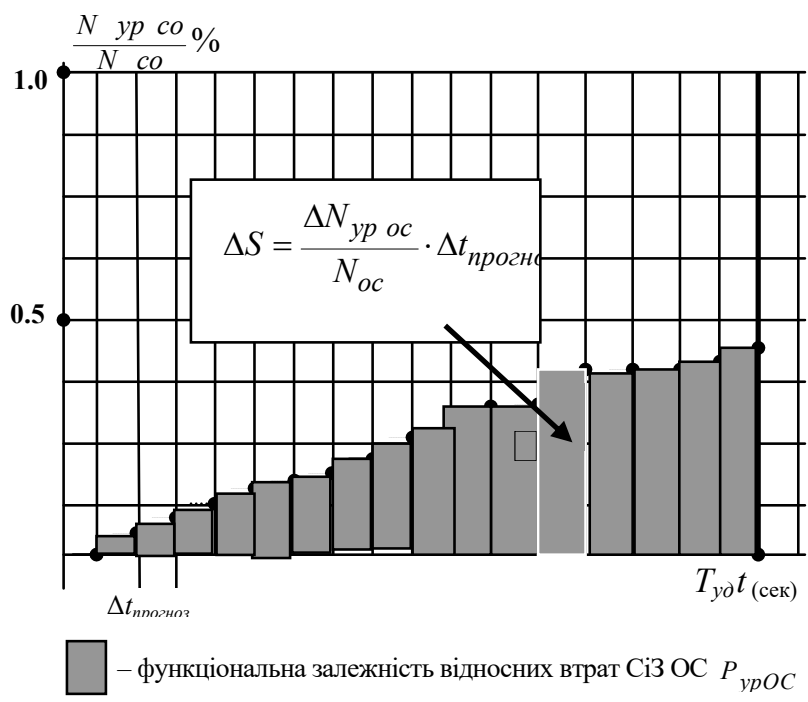

Рис. 3. Пояснення до порядку розрахунку середньозваженої за час удару противника, імовірності ураження Сі3 та Ооб ОС ОТУ

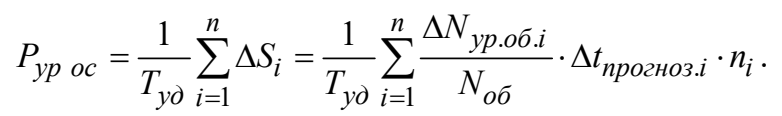

Тоді імовірність збереження Сi3 та Ооб ОС буде рахуватися за формулою:

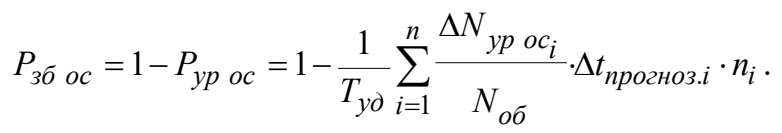

Значення відвернутих втрат $B_{6}$ можливо отримати з останньої формули за наданими вартісними оцінками об'єктів, озброєння та військової техніки.

Таблиці з розрахованими пріоритетами складових $W_{c \kappa r_{i}}$ ОС у подальшому застосовуються для визначення раціональних $n$ варіантів із усіх можливих рішень.

Показниками надійності виконання бойових завдань оборони є: імовірність збереження $\left(P_{3 б}\right)$ не менше заданої кількості (або частки) угрупувань військ, що обороняються, та імовірність знищення не менше заданої кількості (або долі) ВЗУ противника.

Оцінювання якості рішень, що приймаються, зручно проводити з використанням відносних коефіцієнтів ефективності Сі3 ОС та дій противника.

Так коефіцієнт ефективності дій ВЗУ противника дорівнює:

$$
E_{y \partial_{n p}}=\frac{\lambda_{y p}}{\lambda_{0}}=\frac{\frac{N_{y \kappa}}{\Delta t}}{\frac{N_{n_{\text {скл }}}^{\Delta t}}{\Delta t}}=\frac{N_{y \kappa}}{N_{n_{\text {скл }}}},
$$

а коефіцієнт ефективності ОС розраховується за формулою:

$$
E_{o c}=\frac{\sum \Pi_{y p(\sigma p, P B, A p, A B, \Pi \Pi O, \ldots)}}{\lambda_{0}}=\frac{\frac{N_{y p n p}}{\Delta t}}{\frac{N_{n n p}}{\Delta t}}=\frac{N_{y p n p}}{N_{n n p}} .
$$

Коефіцієнт динамічного співвідношення сил сторін, який характеризує співвідношення швидкостей ураження сил сторін, або часток $(\delta)$ знищених ВЗУ противника та Сi3 ОС, розраховується за формулою:

$$
\mathrm{K}_{\partial c}=\frac{\sum \Pi_{y p(\sigma p, P B, A p, A в, \Pi \Pi O, \ldots)}}{\lambda_{y p}}=\frac{\delta_{y p n p}}{\delta_{y p ~ O C}} .
$$

Дослідження закону зміни коефіцієнта динамічного співвідношення дало можливість оцінити здатність Сі3 ОС “витримувати” удар В3У противника заданої інтенсивності при обмеженнях на втрати Сi3 та Ооб. Таке дослідження було проведено методом моделювання з використанням ланчестерської моделі (лінійного закону Ф. Ланчестера) та моделі Осіпова (математична модель масштабного збройного протистояння, що описує втрати сторін). Модель Ланчестера передбачає систему із двох однорідних диференціальних рівнянь для моделювання оборонного бою.

В найбільш загальному вигляді ці моделі можна описати рівнянням:

$$
\left\{\begin{array}{l}
\frac{d x}{d t}=a x+b x y+c y+d \\
\frac{d y}{d t}=e y+f y x+g x+h
\end{array},\right.
$$

де $a$ і $e$-визначають швидкість не бойових втрат;

$b$ i $f$ - швидкість втрат із-за впливу на цілі 3 великою площею;

$c$ i $g$ - втрати від впливу противника на передньому краї;

$d$ i $h$-резерви, які підходять або відходять.

Модель Осіпова (коефіцієнти) $a$ і $e$ визначає кількість втрат пропорційно кількості протилежної сторони. Це можуть бути “класичні” позиційні оборонні дії, де дві сторони знаходяться в умовах безпосереднього зіткнення. Ці дві моделі виявили наступні закономірності. На рис. 4 наведений графік залежності відносних втрат сторін від обраного противником значення допустимих втрат, при якому він відмовиться продовжувати бойові дії (табл. 5). Особливістю реальних оборонних дій, які враховані в моделях, є те, що при закладеному противником значенні рівня допустимих втрат його реальні втра- 
ти (після прийняття рішення щодо відмовлення від виконання подальших завдань) стають більше заданого порогу (рівня). Це пояснюється динамічністю реальних процесів оборонних дій.

Таблиця 5

Таблиця залежності відносних втрат сторін від допустимих втрат противника під час моделювання обраного варіанту побудови ОС ОТУ на $i$-му змодельованому оперативному напрямку

\begin{tabular}{|c|c|c|c|c|c|c|c|c|c|c|c|c|}
\hline \multirow{2}{*}{$\begin{array}{c}\text { Втрати } \\
(\%)\end{array}$} & \multicolumn{12}{|c|}{ Допустимі втрати противника (\%) } \\
\hline & 1 & 2 & 3 & 4 & 5 & 7 & 10 & 15 & 17 & 19 & 20 & 21 \\
\hline $\begin{array}{c}\text { ВзУ } \\
\text { противн. }\end{array}$ & $\stackrel{\infty}{+}$ & to & $\begin{array}{l}n \\
\infty \\
\infty\end{array}$ & $\begin{array}{l}n \\
\infty \\
\infty\end{array}$ & $\approx$ & $\stackrel{n}{=}$ & $\begin{array}{l}0 \\
\pm \\
\square\end{array}$ & $\stackrel{m}{2}^{2}$ & $\stackrel{n}{2}$ & $\stackrel{\infty}{2}$ & ஷ̊ & $\frac{0}{i}$ \\
\hline $\mathrm{CO}$ & 0 & 0 & 0 & 0 & 0 & $\cong$ & $\Rightarrow$ & ते & $\begin{array}{l}\infty \\
\substack{\infty \\
\infty}\end{array}$ & $\begin{array}{l}\text { तี } \\
\text { तn }\end{array}$ & $\begin{array}{l}5 \\
\text { s. }\end{array}$ & $\begin{array}{c}\text { No } \\
\infty \\
\infty\end{array}$ \\
\hline
\end{tabular}

Факт досягнення допустимих втрат та відмовлення від продовження оборонних дій не може зупинити процес вогневого ураження противника вогнем Сi3 OC.

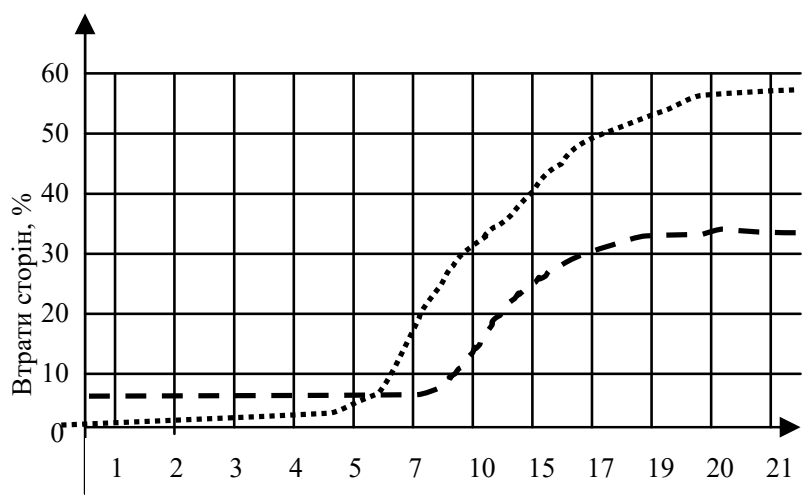

Допустимі втрати ВЗУ противника, \%

... - сили і засоби системи оборони ОТУ;

- $-\mathbf{Z}-\mathbf{-}$ - вогневі засоби ураження противника

Рис. 4. Графік залежності відносних втрат сторін від допустимих втрат ВЗУ противника, при яких він відмовляється від подальших дій

3 графіку видно, що деякий час ВЗУ противника не можуть вражати угрупування військ в обороні 3 достатнім рівнем ураження. При цьому, ефективність ОС ОТУ буде характеризуватися тим, наскільки іiі зони вогневого впливу винесені в бік противника на передньому краю (або за рубежі виконання завдань противником). На початковому етапі оборонних дій дуже важливим стає завдання нанести противнику максимально можливі втрати до того, як він почне уражати Сi3 OC.

Причому доцільно нанести йому такий рівень втрат, який недопустимий для нього та при якому він відмовляється від подальших оборонних дій тоді завдання оборони буде вирішено у повній мірі.

Дослідження показують, що правильне визна- чення напрямку головного удару противником та створення на ньому потужної ОС зі збільшеними вогневими можливостями гарантує досягнення мети оборони та збереження Сi3 OC.

На графіку (рис. 5) чітко визначається очікуваний рівень втрат ВЗУ противника, з перевищенням якого починається ураження Сi3 та Ооб ОС. Цей рівень може бути охарактеризований показником однобічних безкарних втрат противника ( $\left.E_{\text {бви }}\right)$, який визначає рівень втрат, які несе противник від оборонних дій до першого рубежу виконання завдань ВЗУ противника (перших уражених угрупувань військ або об'єктів оборони). Доцільно цей рівень втрат розраховувати у відносних одиницях:

$$
E_{\text {бви }}=\frac{N_{\text {бви }}}{N_{n p}} .
$$

Цей показник характеризує не тільки рівень втрат ВЗУ противника, але й створену систему ОС. Тому, виходячи з заданого рівня безкарних втрат

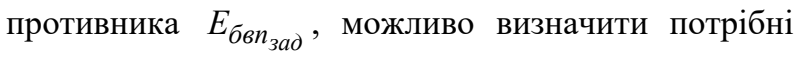
для надійної оборони параметри ОТУ на головному та допоміжних напрямках ударів ВЗУ противника.

В загальному випадку значення рівня безкарних втрат противника буде знаходитися у межах:

$$
E_{\text {бвп зад }}<E_{\text {бви }}<0 .
$$

На основі порівняння значення показника однобічних безкарних втрат противника зі значенням показника його допустимих втрат $E_{n p}$ доn , на які противник може розраховувати у бойових діях, можна характеризувати якість ОС та рішення, що приймається:

$$
E_{\text {бви }}>E_{\text {пр доп }} .
$$

Ci3 OC вважаються більш захищеними, якщо вони мають більше значення показника безкарних втрат $\left(E_{б в n}\right)$. У зв'язку з тим, що при виконанні умови критерію $E_{б в n}>E_{n p}$ доп імовірність збереження Сіз та Ооб ОС збільшується, противник може відмовиться від подальших бойових дій. Це забезпечить досягнення мети ОС - збереження військ i об'єктів оборони.

Під час аналізу результатів моделювання оборонних дій характерно поводить себе й коефіцієнт динамічного співвідношення $\left(K_{\partial c}\right)$ сил сторін, який під час прийняття рішення може застосовуватися як додатковий показник для вибору кращого варіанту побудови ОС (табл. 6 і рис. 5).

Для конкретного варіанту рішення $K_{\partial c}$ (залежно від рівня допустимих втрат ВЗУ противника) може перевищувати значення одиниці й, тим самим, характеризувати переважні вогневі можливості угруповання військ в обороні над противником. 
Таблиця 6

Таблиця залежності коефіцієнту динамічного співвідношення сил сторін від допустимих втрат

ВЗУ противника під час модулювання обраного варіанту побудови ОС ОТУ на $i$-му змодельованому оперативному напрямку

\begin{tabular}{|c|c|c|c|c|c|c|c|c|c|c|c|c|}
\hline & \multicolumn{12}{|c|}{ Допустимі втрати противника (\%) } \\
\hline & 1 & 2 & 3 & 4 & 5 & 7 & 10 & 15 & 17 & 20 & 25 & 30 \\
\hline Кдс & 0 & o & 0 & 0 & 0 & $\begin{array}{l}n \\
\infty \\
0 \\
0\end{array}$ & $\begin{array}{l}\infty \\
\infty \\
\infty \\
-1\end{array}$ & $\mid \begin{array}{l}\hat{\infty} \\
0 \\
0\end{array}$ & $\frac{\frac{g}{I}}{\sigma_{0}}$ & $\begin{array}{l}\text { के } \\
\text { ?n } \\
\text { ? }\end{array}$ & $\begin{array}{l}n \\
n \\
n \\
o\end{array}$ & $\begin{array}{l}\text { Uై } \\
\text { ర. }\end{array}$ \\
\hline
\end{tabular}

Чим вище від одиниці значення показника $K_{\partial c}$, чим більше термін часу цього періоду оборонних дій, тим краще побудована ОС й прийняте рішення на оборону.

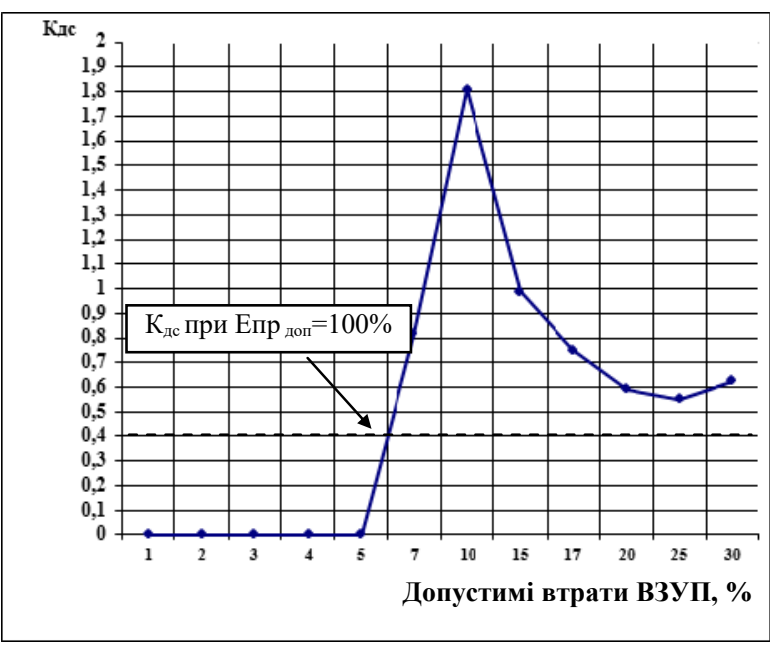

Рис. 5. Графік зміни коефіцієнту динамічного співвідношення втрат сторін залежно від допустимих

втрат ВЗУ противника під час моделювання оборонних дій в обраному варіанті побудови ОС ОТУ на $i$-му змодельованому оперативному напрямку

Формування функціональних залежностей 3 використанням моделі двосторонніх бойових дій [13] супроводжувалося зупиненням процесу моделювання під час досягнення значення допустимих втрат ВЗУ противника.

Таким чином, здійснювався зріз стану процесів при обраних значеннях $E_{n p}$ доn за часом наступальних дій противника. Це дозволило побудувати графік (рис. 5), який показує характер залежності $K_{\partial c}$ від часу з початку бойових дій на протязі всього часу наступальних дій противника.

Практичні випробування моделі двосторонніх бойових дій при фіксованому значенні рівня допустимих втрат противника 100\% дають усталене значення $K_{\partial c}$. Графік характеризує першу похідну функцію залежності втрат ВЗУ противника від часу, що закономірно пояснює реальні фізичні процеси, які моделюються. Не всі варіанти побудови ОС ОТУ під час аналізу результатів моделювання давали $K_{\partial c}>1$. Вимогу до розглянутого показника $K_{\partial c}$, який повинен бути більше одиниці, та критерій за втратами противника (5) доцільно включити до системи оцінки рішень на оборону, що приймаються. Їх доцільно обгрунтовувати за всім переліком критеріїв ефективності ОС ОТУ, які у сукупності дають можливість сформувати повну множину пропозицій-альтернатив та врахувати конкретні умови вибору варіантів рішень. 3 цього слідує, що в систему оцінки рішень доцільно включити відомий [1113] перелік критеріїв оцінки ефективності ОС:

- досягнення заданого значення ефективності системи оборони $E_{o c}>E_{\text {ос зад }}$;

- недопущення запланованого значення ефективності наступальних дій ВЗУ противника

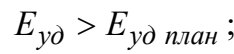

- забезпечення імовірності збереження Сi3 та

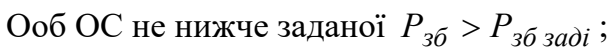

- забезпечення збереження Сi3 та Ооб ОС даного типу не менше заданої кількості

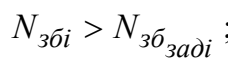

- досягнення заданого значення відвернутих втрат $B_{6}>B_{B_{\text {зад }}}$ - для оцінки рішень на стратегічному рівні управління (державна оцінка ефективності);

- вибір рішення на оборону, при якому коефіцієнт статичного співвідношення більше заданого $\left(K_{c}>K_{c_{3 a \partial}}\right)$;

- вибір рішення на оборону, при якому коефіцієнт динамічного співвідношення $K_{\partial c}>1$;

- вибір рішення на оборону, при якому забезпечується збереження Сi3 та Ооб ОС при значенні безкарних втрат противника більше заданого, або більше допустимого рівня втрат ВЗУ противника $E_{\text {бви }}>E_{\text {бви }}, E_{\text {бви }}>E_{\text {пр доп }} ;$

- критерій $з$ точки зору вибору варіантів наступу противника (для моделювання оборонних дій), де ефективність удару повинна бути не нижче заданої $E_{y \partial}>E_{y \partial_{\text {зад }}}$. Даний критерій використовується під час планування вогневого ураження ВЗУ противника в місцях їх базування ударною компонентою ОС OTУ.

За допомогою методу аналізу ієрархій доцільно проаналізувати пріоритетність кожного із критеріїв, що дасть змогу використовувати їх під час вибору варіантів рішень, що приймаються. Значення пріоритетів закладаються у бази даних програмнотехнічного комплексу для наступного використання під час модулювання обраного варіанту побудови ОС ОТУ на $i$-му змодельованому оперативному 
напрямку (табл. 6).

Відношення узгодженості (ВУ) $=0,058$ (5,8\%) дає змогу погодитися 3 визначеними пріоритетами кожного критерію, що у подальшому дає право їх використовувати в процесі прийняття рішення для формування інтегральної оцінки (Io).

Для автоматизації процесу оцінки пропозицій щодо пошуку раціонального варіанту рішення [21] на оборону, доцільно звести його до наступних кроків:

- за заданими значеннями показників ефективності ОС на основі застосування системи математичних моделей та задач знайти конкретні значення макропараметрів угруповань бр (опдбр, омбр, омпбр та огшбр), ракетних військ, артилерії, авіації, ППО та військ забезпечення;

- в рамках парето-оптимізації обмежитись областю значень, які відповідають обраним критеріям;

- за результатами автоматизації процесу оцінки конкретної обстановки (оцінки противника, своїх військ, оцінки створеної ОС, стану Сі3 ОС ОТУ на сусідньому оперативно-тактичному напрямку $(\mathrm{OTH})$ ) та на підставі проведеного моделювання бойових дій [22], визначити варіанти наступальних дій противника, кількість ВЗУ, напрямки головного удару ВЗУ, остаточні параметри Сі3 ОС та систем забезпечення (з врахуванням виділеного резерву) для виконання завдань оборони на ОТН з визначеною ефективністю в очікуваному діапазоні умов дій противника. При цьому кількість комбінацій конкретних значень параметрів Сi3 ОС буде характеризуватись множиною значень параметрів за декількома варіантами рішень, однак усі ці комбінації будуть припустимі за обраними показниками ефективності ОС. Тому, далі із множини варіантів обирається конкретний варіант рішення методом аналізу ієрархій з врахуванням пріоритетів кожної складової рішення на оборону та ваги пріоритету кожного показника ефективності ОС.

Таке завдання доцільно вирішувати у три етапи. На першому emani за допомогою аналітикостохастичних моделей [23] обрати раціональні макропараметри Сi3 OC, тому що на відміну від детермінірованих моделей, вони враховують імовірнісний характер параметрів об'єкту, що моделюється, на шталт в моделі ОС ОТУ. В цій моделі неможливо точно визначити час, сили і засоби та напрямок наступальних дій противника. Ці дані $є$ імовірнісними, тому модель ОС ОТУ є стахостичною, тобто значення змінних величин моделі, що залежать від реалізації імовірних величин, самі стають імовірнісними величинами. Аналіз таких моделей виконується на ПЕОМ на основі статистики, що накопичується у ході імітаційних експериментів при багатократному прогоні моделі для різних значень вихідних імовірнісних величин, що відібрані у відповідності 3 їх статистичними характеристиками.

На другому emani за допомогою імітаційних моделей [24-25] провести вибір та уточнення детальних параметрів складових ОС ОТУ за декількома варіантами в інтерактивному режимі із застосуванням електронних карт рельєфу місцевості.

На третьому етапi із застосуванням алгоритму реалізації методу аналізу ієрархій відібрати 3 декількох варіантів (як правило до 9) один, який $з$ врахуванням обчислених значень показників якості Ci3 ОС, відповідатиме раціональному рішенню. Варіанти рішень розташовуються за їх пріоритетами, з яких командиру ОТУ необхідно погодитися 3 рекомендаціями, які формуються автоматизовано (завдяки спеціальним комп'ютерним програмам) [26], або обрати рішення за своїм розумінням 3 того переліку, який наданий для розгляду. Після прийняття рішення на електронній карті та в комп'ютерних базах даних формуються усі формалізовані документи, що відповідають елементам рішення.

В процесі прийняття рішення на оборону в ЦОУ ОТУ на тривалий період часу передбачається використовування математичних моделей.

Отже, використовуючи методику визначення критеріїв та показників динаміки оборонних дій як інструмент роботи командування та офіцерів штабу ОТУ, можна знайти макропараметри Сi3 OC, ї показники ефективності та оцінити за обраними критеріями пропозиції посадових осіб ЦОУ.

Таким чином, командиру ОТУ надається можливість із множини варіантів прийняти раціональне рішення на організацію ефективної ОС у відповідності з обстановкою, яка складається.

\section{Висновки}

Ефективність ОС ОТУ може характеризуватися системою просторових, часових, імовірнісних і кількісних показників.

Під час визначення й обгрунтуванні критеріїв та показників ефективності ОС для прийняття командиром ОТУ рішення на оборону доцільно використовувати такі положення:

- сутність ОС, іï якісна специфіка та властиві їй системні й інтегровані якості;

- склад, кількісна й якісна характеристика окремих Сi3 та Ооб ОС;

- структура, тобто внутрішня організація, взаємозв'язок окремих елементів Сi3 та Ооб ОС, їх поєднання та взаємодія;

- функції ОС, іiі активність, боєздатність та функції окремих їі елементів Сі3 та Ооб ОС;

- механізми, що забезпечують цілісність ОС, взаємодію, удосконалення та розвиток;

- здійснення зв’язку з зовнішнім середовищем. 
Таким чином, визначені критерії й показники та розроблені математичні моделі ефективності Сi3 та Ооб ОС ОТУ є важливим науковим завданням, вирішення якого в значній мірі дозволить динамічно моделювати оборонні дії Сi3 на конкретно визначеному напрямку та допоможуть обгрунтувати пропозиції для прийняття раціонального рішення на оборону.

\section{Список літератури}

1. Лобанов А.А. Нормативно-правова база функціонування системи забезпечення воєнної безпеки України: проблеми і шляхи вирішення [Текст] / А.А. Лобанов // Труди академії. - К. : НАОУ, 2008. - № 4(84). - С. 5-8.

2. Лобанов А.А. Система забезпечення воєнної безпеки України та проблеми відповідності структури функціональному призначенню [Текст] / А.А. Лобанов, В.М. Грубов // Збірник праць ННДЦ ОТ і ВБ України. - К. : ННДЦ ОТ і ВБ, 2008. - № 1(38) - С. 112-118.

3. Варакута В.П. Заходи щодо посилення блокпостів і опорних пунктів як елементів системи оборони в умовах ведення оборонного бою проти незаконних збройних формувань [Текст] / В.П. Варакута, А.В. Чухлатий, І.А. Пегахін // Честь і закон. - Х.: НАНГУ, 2015. - № 2. - С. 15-22.

4. Лобанов А.А. Алгоритм визначення пріоритетних завдань, покладених на систему забезпечення воєнної безпеки держави [Текст] / А.А. Лобанов, В.А. Кириленко. - К.: ЗНП НАДПС України серія: військові та технічні науки. - 2013. Вип. № 2. - С. 109-116.

5. Лотов О.В. Многокритериальные задачи принятия решений / О.В. Лотов, И.И. Поспелова. - М. : МАКС Пресс, 2008. $-197 \mathrm{c}$.

6. Рыков О.С. Системный анализ. Модели и методы принятия решений и поисковой оптимизации: монография / О.С. Рыков. - М.: Издательский Дом МИСиС, 2009. - 608 с.

7. Саати Т.Л. Принятие решений при зависимостях и обратных связях. Аналитические сети / Т.Л. Саати. - М.: Издательство ЛКИ, 2008. - 360 с.

8. Маврина И.А. Организация управления социальной работой (научное редактирование) / И.А. Маврина, Т.Н. Вишнякова, И.Н. Чередниченко. - Омск.: Издательство ОмГПУ, 2010. - 94 с.

9. Вибір показників ефективності для оцінки взаємодії зенітних ракетних військ та винищувальної авіації [Текст] / С.І. Бурковський, М.О. Стахєєв, О.М. Місюра та ін. // Системи обробки інформації. - Х. : ХУПС, 2007. - Вип. 5(63). C. $15-18$.

10. Система показників можливостей бригади оперативного призначення Національної гвардії України у спеціальній операції зі знешкодження незаконних збройних формувань [Текст] / В.П. Варакута, Г.А. Дробаха, І.А. Луговський, С.М. Гніденко // Честь і закон”. - Х.: НАНГУ, 2015. - № 1. - С. 35-45.

11. Жарик О.М. Показники і критерії оцінки ефективності прикриття важливих державних об'єктів і угрупувань військ (сил) [Текст] / О.М. Жарик. - Х. : Наука і техніка Повітряних Сил Збройних Сил України. - 2012. - № 3(9). C. $18-26$.

12. Барвиненко В. Еще раз о показателях и критериях [Текст] / В. Барвиненко, Ю. Аношко // Воздушнокосмическая оборона. -2014. - № 3. - С. 17-28.

13. Ногин В.Д. Принятие решений в многокритериальной среде. Количественный подход / В.Д. Ногин. - М.: Физматлит, 2002. $-144 \mathrm{c}$.

14. Протиріччя, що виникають у ході загальновійськового бою та шляхи їх вирішення / I.А. Пегахін, С.О. Стародубцев, В.П. Варакута, О.С. Забула, О.Ю. Чернявський // Збірник наукових праць Харківського національного університету Повітряних Сил. - 2017. - № 2(51). - С. 17-24.

15. Обгрунтування залежності результату загальновійськового бою від рівня якості змістовності управлінської інформації / В.П. Варакута, М.В. Левицький, Д.В. Дяченко, С.О. Стародубцев, О.С. Забула // Збірник наукових праць Харківського національного університету Повітряних Сил. - 2018. - № 1(55). - С. 8-16. https://doi.org/10.30748/zhups.2018.55.01.

16. Основи теорії військового управління та штабні процедури НАТО / В.П. Варакута, І.Ф. Ролін та ін. - Х.: ВITВ НТУ “ХПІ", 2019. - 296 с.

17. Варакута В.П. Історія війн та воєнного мистецтва (у т.ч. історія українського війська) / В.П. Варакута, І.М. Криленко. - Х.: ВІТВ НТУ “ХПІ”, 2019. - 274 с.

18. Садовский Л.Е. Коды и математика / Л.Е. Садовский, М.Н. Аршинов. - М.: Наука, 1983. - 144 с.

19. Колмогоров А.Н. Математика XIX века. Теория вероятностей / А.Н. Колмогоров, А.П. Юшкевич. - М.: Наука, 1978. $-254 \mathrm{c}$.

20. Саати Т.Л. Принятие решений. Метод анализа иерархий / Т.Л. Саати. - М.: Радио и связь, 1993. -278 с.

21. Бідюк П.І. Інтелектуальні системи підтримки прийняття рішень / П.І. Бідюк, І.В. Баклан, О.В. Нестеренко. - Київ: НАУ, 2015. - $218 \mathrm{c}$.

22. Стеценко І.В. Моделювання систем / І.В. Стеценко. - Черкаси: ЧДТУ, 2010. - 399 с.

23. Андрєєв М.В. Оптимізація стохастичних моделей. Спецкурс. Керовані марковські та напівмарковські моделі 3 повною й неповною інформацією / М.В. Андрєєв.- К.: Видавництво АПСВ, 2012. - 240 с. $108 \mathrm{c}$.

24. Кравець І.О. Імітаційне моделювання / І.О. Кравець. - Миколаїв: Видавництво ЧдУ ім. Петра Могили, 2010. -

25. Неруш В.Б. Імітаційне моделювання систем та процесів / В.Б. Неруш, В.В. Курдеча. - К.: НН ІТС НТУУ “КПІ”, 2012. -115 c.

26. Методична система опанування стандартами та штабними процедурами НАТО як чинник досягнення творчого рівня компетенції при їх імплементації / В.П. Варакута, О.А. Макогон, І.М. Криленко, О.В. Соколіна // Збірник наукових праць військового інституту Київського національного університету ім. Тараса Шевченка 2019. - № 63. - С. 130-138. 


\section{References}

1. Lobanov, A.A. (2008), "Normatyvno-pravova baza funktsionuvannya systemy zabezpechennya voyennoyi bezpeky Ukrayiny: problemy i shlyakhy vyrishennya" [The legal framework for the functioning of Ukraine's military security system: problems and solutions], Trudy akademiyi, Natsional'na akademiya oborony Ukrayiny, No. 4(84), Kyiv, pp. 5-8.

2. Lobanov, A.A. and Ghrubov, V.M. (2008), "Systema zabezpechennya voyennoyi bezpeky Ukrayiny ta problemy vidpovidnosti struktury funktsional'nomu pryznachennyu" [The system of ensuring the military security of Ukraine and the problem of compliance of the structure with its functional purpose], Collection of works NNDTS OT $i$ VB Ukrayiny, No. 1(38), Kyiv, pp. 112-118.

3. Varakuta, V.P., Chukhlatyy, A.V. and Peghakhin, I.A. (2015), "Zakhody shchodo posylennya blokpostiv i opornykh punktiv yak elementiv systemy oborony $\mathrm{v}$ umovakh vedennya oboronnoho boyu proty nezakonnykh zbroynykh formuvan" [Measures to strengthen roadblocks and strongholds as elements of the defense system in the context of a defensive battle against illegal armed groups], Honor and Law, No. 2, Kharkiv National Academy of National Guard of Ukraine, pp. 15-22.

4. Lobanov, A.A. and Kyrylenko, V.A. (2013), "Alhorytm vyznachennya priorytetnykh zavdan', pokladenykh na systemu zabezpechennya voyennoyi bezpeky derzhavy" [An algorithm for determining the priority tasks assigned to the state's military security system], ZNP NADPS Ukrayiny seriya: viys'kovi ta tekhnichni nauky, No. 2, Kyiv, pp. 109-116.

5. Lotov, O.V. and Pospelova, I.I. (2008), "Mnogokriterial'nyye zadachi prinyatiya resheniy" [Multi-Criteria for Decision Making], MAKS Press, Moscow, 197 p.

6. Rykov, O.S. (2009), "Sistemnyy analiz. Modeli i metody prinyatiya resheniy i poiskovoy optimizatsii: monografiya" [System analysis. Models and methods of decision making and search engine optimization: monograph], Izdatel'skiy Dom MISiS, Moscow, $608 \mathrm{p}$.

7. Saati, T.L. (2008), "Prinyatiye resheniy pri zavisimostyakh i obratnykh svyazyakh. Analiticheskiye seti" [Decision making with dependencies and feedbacks. Analytical Networks], Izdatel'stvo LKI, Moscow, 360 p.

8. Mavrina, I.A., Vishnyakova, T.N. and Cherednichenko, I.N. (2010), "Organizatsiya upravleniya sotsial'noy rabotoy (nauchnoye redaktirovaniye)" [Organization of social work management (scientific editing)], Izdatel'stvo OmGPU, Omsk, 94 p.

9. Burkovs'kyy, S.I. Stakhyeyev, M.O. and Misyura, O.M. (2007), "Vybir pokaznykiv efektyvnosti dlya otsinky vzayemodiyi zenitnykh raketnykh viys'k ta vynyshchuval'noyi aviatsiyi" [Selection of performance indicators for assessing the interaction of anti-aircraft missile forces and fighter aircraft], Information Processing Systems, No. 5(63), pp. 15-18.

10. Varakuta, V.P., Drobakha, H.A. Lughovsjkyj, I.A. and Ghnidenko, S.M. (2015), "Systema pokaznykiv mozhlyvostey bryhady operatyvnoho pryznachennya Natsional'noyi hvardiyi Ukrayiny u spetsial'niy operatsiyi zi zneshkodzhennya nezakonnykh zbroynykh formuvan" [System of Indicators of Capabilities of the Operational Assignment Brigade of the National Guard of Ukraine in a Special Operation to Eliminate Illegal Armed Forces], Honor and Law, No. 1, pp. 35-45.

11. Zharyk, O.M. (2012), "Pokaznyky i kryteriyi otsinky efektyvnosti prykryttya vazhlyvykh derzhavnykh ob'yektiv i uhrupuvan viys'k (syl)" [Indicators and Criteria for Evaluating the Effectiveness of Covering Major State Objects and Forces (Forces)], Science and Technology of the Air Force of Ukraine, No. 3(9), pp. 18-26.

12. Barvynenko, V. and Anoshko, Yu. (2014), "Eshche raz o pokazatelyakh y kryteryyakh" [Once again about indicators and criteria], Vozdushno-kosmycheskaya oborona, No. 3, pp. 17-28.

13. Nohyn, V.D. (2002), "Prynyatye reshenyy v mnohokryteryal'noy srede. Kolychestvennyy podkhod" [Decision making in a multi-criteria environment. Quantitative approach], Fyzmatlyt, Moscow, $144 \mathrm{p}$.

14. Pehakhin, I.A., Starodubtsev, S.O., Varakuta, V.P., Zabula, O.Ye. and Cherniavskyi, O.Yu. (2017), "Protyrichchia, shcho vynykaiut $u$ khodi zahalnoviiskovoho boiu ta shliakhy yikh vyrishennia" [Contradictions arising in the current of community fighting and the way of their solution], Scientific Works of Kharkiv National Air Force University, Vol. 2(51), pp. 17-24.

15. Varakuta, V.P., Levytskyi, M.V., Diachenko, D.V., Starodubtsev, S.O. and Zabula, O.Ye. (2018), "Obgruntuvannia zalezhnosti rezultatu zahalnoviiskovoho boiu vid rivnia yakosti zmistovnosti upravlinskoi informatsii" [Kationale of the dependence of the results of the general boy from the level of quality content of management information], Scientific Works of Kharkiv National Air Force University, Vol. 1(55), pp. 8-16. https://doi.org/10.30748/zhups.2018.55.01.

16. Varakuta, V.P. and Rolin, I.F. (2019), "Osnovy teoriyi viys'kovoho upravlinnya ta shtabni protsedury NATO” [Basics of Military Management Theory and Staffing Procedures of NATO], Military Institute of Tank Troops NTU "KHPI", Kharkiv, $296 \mathrm{p}$.

17. Varakuta, V.P. and Krylenko, I.M. (2019), "Istoriya viyn ta voyennoho mystetstva (u t.ch. istoriya ukrayins'koho viys'ka)" [History of wars and martial arts (including the history of the Ukrainian army)], Military Institute of Tank Troops NTU "KHPI", Kharkiv, 274 p.

18. Sadovskiy, L.Ye. and Arshinov, M.N. (1983), "Kody i matematika" [Codes and Math], Nauka, Moscow, 144 p.

19. Kolmogorov, A.N. and Yushkevich, A.P. (1978), "Matematika 19 veka. Teoriya veroyatnostey" [Mathematics of the 19th century. Probability theory], Nauka, Moscow, 254 p.

20. Saati, T.L. (1993), "Prinyatiye resheniy. Metod analiza iyerarkhiy" [Making decisions. Hierarchy Analysis Method], Radio i svyaz', Moscow, 278 p.

21. Bidyuk, P.I., Baklan, I.V. and Nesterenko, O.V. (2015), "Intelektual'ni systemy pidtrymky pryynyattya rishen" [Intelligent decision support systems], NAU, Kyiv, 218 p.

22. Stetsenko, I.V. (2010), "Modelyuvannya system" [Systems modeling], Cherkasy State Technical University, Cherkasy, $399 \mathrm{p}$.

23. Andryeyev, M.V. (2012), “Optymizatsiya stokhastychnykh modeley. Spetskurs. Kerovani markovs'ki ta napivmarkovs'ki modeli z povnoyu y nepovnoyu informatsiyeyu" [Stochastic model optimization. Special course. Managed Marked and SemiMarked Models with complete and incomplete information], Vydavnytstvo APSV, Kyiv, $240 \mathrm{p}$.

24. Kravets', I.O. (2010), "Imitatsiyne modelyuvannya" [Simulation modeling], Vydavnytstvo CHDU im. Petra Mohyly, Mykolayiv, $108 \mathrm{p}$.

25. Nerush, V.B. and Kurdecha, V.V. (2012), "Imitatsiyne modelyuvannya system ta protsesiv" [Simulation modeling of systems and processes], NN ITS NTUU “KPI”, Kyiv, $115 \mathrm{p}$.

26. Varakuta, V.P., Makohon, O.A., Krylenko, I.M. and Sokolina, O.V. (2019), "Metodychna systema opanuvannya standartamy ta shtabnymy protseduramy NATO yak chynnyk dosyahnennya tvorchoho rivnya kompetentsiyi pry yikh 
implementatsiyi" [The methodological system of mastering NATO standards and staff procedures as a factor in achieving a creative level of competence in their implementation], Zbirnyk naukovykh prats' viys'kovoho instytutu Kyyivs'koho natsional'noho universytetu imeni Tarasa Shevchenka, No. 63, pp. 130-138.

\section{Відомості про авторів:}

Варакута Володимир Павлович кандидат військових наук доцент доцент кафедри

Військового інституту танкових військ НТУ “ХПІ”, Харків, Україна

https//orcid.org/0000-0002-5759-8758

\section{Кумпан Олександр Олександрович}

заступник начальника кафедри

Військового інституту танкових військ НТУ “ХПІ”, Харків, Україна

https//orcid.org/0000-0001-7867-1742

\section{Хліманцов Тарас Володимирович}

старший викладач

Військового інституту танкових військ НТУ “ХПІ”,

Харків, Україна

https//orcid.org/0000-0002-8301-1674

\section{Іванов Володимир Олександрович}

старший викладач

Військового інституту танкових військ НТУ “ХПІ”, Харків, Україна

https//orcid.org/0000-0002-0895-5405

\section{Заверуха Григорій Валентинович} викладач

Військового інституту танкових військ НТУ “ХПІ”, Харків, Україна

https//orcid.org/0000-0001-7447-2033

\section{Information about the authors:}

\section{Volodymyr Varakuta}

Candidate of Military Science Associate Professor Senior Lecturer

of Military institute of Tank Troops NTU "KhPI", Kharkiv, Ukraine

https//orcid.org/0000-0002-5759-8758

\section{Oleksandr Kumpan}

Deputy Head of the Department

of Military Institute of Tank Troops NTU "KhPI", Kharkiv, Ukrain

https//orcid.org/0000-0001-7867-1742

\section{Taras Hlimancov}

Senior Instructor

of Military Institute of Tank Troops NTU "KhPI", Kharkiv, Ukraine

https//orcid.org/0000-0002-8301-1674

\section{Volodymyr Ivanov}

Senior Instructor

of Military Institute of Tank Troops NTU "KhPI", Kharkiv, Ukraine

https//orcid.org/0000-0002-0895-5405

\section{Grygoriy Zaverukha}

Instructor

of Military Institute of Tank Troops NTU "KhPI", Kharkiv, Ukraine

https//orcid.org/0000-0001-7447-2033

\title{
ОПРЕДЕЛЕНИЕ КРИТЕРИЕВ И ПОКАЗАТЕЛЕЙ ЭФФЕКТИВНОСТИ ОБОРОННОЙ СИСТЕМЫ И РАЗРАБОТКА МОДЕЛИ СИЛ И СРЕДСТВ ОПЕРАТИВНО-ТАКТИЧЕСКОЙ ГРУППИРОВКИ ДЛЯ ОБОСНОВАНИЯ ПРЕДЛОЖЕНИЙ К ПРИНЯТИЮ РЕШЕНИЯ НА ОБОРОНУ
}

\author{
В.П. Варакута, А.А. Кумпан, Т.В. Хлиманцов, В.А. Иванов, Г.В. Заверуха
}

Суверенитет державы Украина обеспечивается созданием и эффективным развитием соответствующих институтов власти, из которых одним из важных есть система обеспечения военной безопасности, включающая войсковую и правоохранительную составляюшую. Проведенный анализ говорит о том, что, к сожалению, эффективность функиионирования некоторых институтов власти согласно политико-экономическим внешним и внутренним рычагам воздействия остается достаточно низкой. Также это касается военной составляющей, а именно: управленческой деятельности командованиями войсковыми операциями объединенных сил и оперативно-тактических группировок войск, которые на линиях соприкосновения сдерживают незаконные вооруженные формирования и российскосепаратистских войсковых формирований от продвижения в глубину территории страны.

Неоправданные потери среди личного состава в боях под Иловайском, Дебальцевом говорят о том, что имеют место непродуманные некоторыми командирами и начальниками решения на оборонительные действия. Принятие решения на боевые действия - это сложный творческий процесс, в котором принимают участие достаточное количество военных специалистов.

Например, решения, которые принимает командир оперативно-тактической группировки на оборону, состоит из предложений должностных лии, закрепленных за отдельными направлениями боевого применения родов войск, специальных войск и войск обеспечения. Эти предложения за соответствующими показателями должны удовлетворять требованиям выбранных критериев.

В статье на понятийном уровне рассмотрена сущность и содержание понятий “критерий” и “показатель” и их значение во время оценки эффективности оборонной системы оперативно-тактической группировки. Кроме того, рассмотрены математические модели и методики определения приоритетных критериев и показателей эффективности оборонной системы и рекомендованы обоснованные предложения путей создания эффективной оборонной системы оперативно-тактической группировки.

Таким образом, определение критериев и показателей эффективности оборонной системы оперативно- 
тактической группировки для обоснования предложений для принятия решения на оборону есть важное научное задание, решение которого в значительной степени позволяет динамично ее развивать и существенно повышать эффективные (боевые, функциональные) возможности оборонной системы, согласно принятому рациональному решению на оборону.

Ключевые слова: критерии, показатели, математические модели, эффективность обороны, оперативнотактическая группировка, принятие решения, рациональное решение, элементы оборонной системы, силы и средства обороны, система управления.

\section{DEFINITION OF CRITERIA AND INDICATORS OF EFFICIENCY OF THE DEFENSE SYSTEM AND DEVELOPMENT OF A MODEL OF FORCES AND MEANS OF OPERATIONAL AND TACTICAL GROUPING FOR SUBSTANTIATION OF PROPOSALS FOR DECISION ON DEFENSE}

The sovereignty of the power of Ukraine is ensured by the creation and effective development of the relevant institutions of power, of which one of the most important is the military security system, including the military and law enforcement component. The analysis suggests that, unfortunately, the effectiveness of the functioning of some institutions of power according to the political and economic external and internal leverage remains quite low. This also applies to the military component, namely: the management of the combined operations forces and operational-tactical groupings by the military operations command, which, on the contact lines, restrain illegal armed groups and Russian-separatist military forces from moving deeper into the country.

Unjustified losses among the personnel in the battles near Ilovaisk, Debaltsev, indicate that there are ill-conceived decisions by some commanders and chiefs on defensive actions. Decision-making on military operations is a complex creative process in which a sufficient number of military specialists take part.

For example, the decisions made by the commander of an operational-tactical defense group consist of proposals from officials assigned to certain areas of the combat employment of the combat arms, special forces and support troops. These proposals for relevant indicators should satisfy the requirements of the selected criteria.

The essence and content of the concepts "criterion" and "indicator" and their significance during the assessment of the effectiveness of the defense system of an operational-tactical grouping are examined at a conceptual level. In addition, mathematical models and methods for determining priority criteria and indicators of the effectiveness of the defense system are considered and reasonable proposals for ways to create an effective defense system of an operational-tactical group are recommended.

Thus, the definition of criteria and performance indicators of the defense system of an operational-tactical group for substantiating proposals for deciding on defense is an important scientific task, the solution of which to a large extent allows it to be dynamically developed and significantly increase the effective (combat, functional) capabilities of the defense system, according to a rational defense decision.

Keywords: criteria, indicators, mathematical models, defense effectiveness, operational-tactical grouping, decision making, rational decision, elements of the defense system, defense forces and equipment, control system. 